\title{
May it Please the Senate: An Empirical Analysis of the Senate Judiciary Committee Hearings of Supreme Court Nominees, 1939-2009
}

Lori A. Ringhand

University of Georgia School of Law, ringhand@uga.edu

Paul M. Collins Jr.

University of North Texas

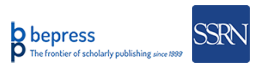

\section{Repository Citation}

Lori A. Ringhand and Paul M. Collins Jr., May it Please the Senate: An Empirical Analysis of the Senate Judiciary Committee Hearings of Supreme Court Nominees, 1939-2009, 60 Am. U. L. Rev. 589 (2011), Available at: https://digitalcommons.law.uga.edu/fac_artchop/691

This Article is brought to you for free and open access by the Faculty Scholarship at Digital Commons @ University of Georgia School of Law. It has been accepted for inclusion in Scholarly Works by an authorized administrator of Digital Commons @ University of Georgia School of Law. Please share how you have benefited from this access For more information, please contact tstriepe@uga.edu. 


\title{
MAY IT PLEASE THE SENATE: AN EMPIRICAL ANALYSIS OF THE SENATE JUDICIARY COMMITTEE HEARINGS OF SUPREME COURT NOMINEES, 1939-2009
}

\author{
LORI A. RINGHAND* \\ PAul M. Collins, JR. ${ }^{\dagger}$
}

TABLE OF CONTENTS

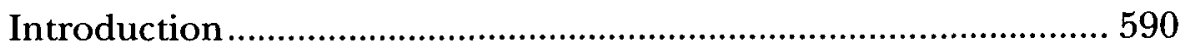

I. The Supreme Court Confirmation Hearings Database.......... 594

II. Data Analysis ...................................................................... 597

A. The Quantity of Comments Over Time …....................... 598

B. Issues and Subissues .....................................................60 600

1. Hearing administration and chatter ........................603

2. Civil rights ...........................................................6 603

a. Race and gender/sexual orientation discrimination ................................................. 608

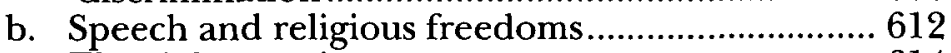

c. The right to privacy ................................................6 614

3. Judicial philosophy .............................................6 617

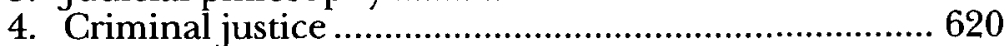

C. Issue Areas and Partisan Affiliation ............................... 620

1. The effect of partisan affiliation ............................. 622

2. The interaction of the partisanship of senators and

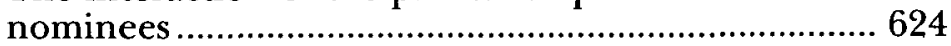

D. Nominee Race and Gender ........................................ 628

III. Conclusions: "The More Things Change, the More They

Stay the Same"

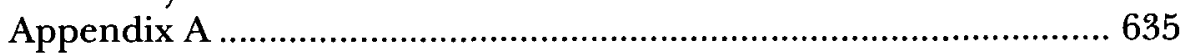

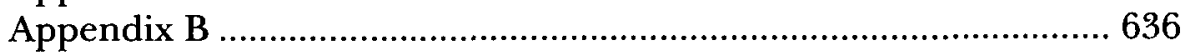

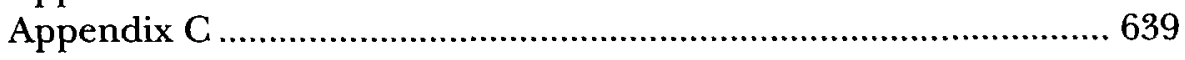




\section{INTRODUCTION}

Supreme Court confirmation hearings have been called many things over the years: a "mess," a "subtle minuet," and, most colorfully, a "kabuki dance." We, however, believe that they areand should be-more than this. The confirmation hearings held before the Senate Judiciary Committee are an essential part of the checks and balances system built into the United States Constitution. These hearings are the point at which an independent judiciary confronts political accountability. They are the point at which we as a nation, acting through our elected officials, accept, refute, and debate decisions of our High Court. Supreme Court confirmation hearings, in short, are the way in which "We the People" take ownership of the Constitution by deciding who we will allow to interpret it on our behalf.

Despite the importance of the hearings, there has been very little empirical research examining exactly what happens when nominees appear before the Senate Judiciary Committee. Political scientists have explored the dynamics of the confirmation process, but have rarely examined the hearings themselves. ${ }^{4}$ Work that has focused on the hearings directly has done so in only limited ways for the purpose

\footnotetext{
*Associate Professor of Law, University of Georgia College of Law.

${ }^{\dagger}$ Assistant Professor of Political Science, University of North Texas. The authors are grateful to the research assistants whose diligent work made this project possible: Bryan Calvin, Nathan Goodrich, Nick Jones, and Jonathan Milby. We also received helpful comments on early drafts from Paul Heald, Dan Lorentz, Liz Oldmixon, and Lisa Solowiej. Finally, we thank Kirk Randazzo and the National Science Foundation for convening the Workshop on the Identification and Integration of Law and Court Data, which was fundamental to bringing this project to fruition. Naturally, we are solely responsible for any errors in fact and/or judgment.

1. See Richard Brust, No More Kabuki Confirmations, 95 A.B.A. J. 39, 39 (2009) (quoting long-time critic of the nomination process Professor Stephen L. Carter).

2. See id. (quoting Senator Arlen Specter).

3. See id. (quoting then-Senator Joe Biden during his tenure on the Senate Judiciary Committee).

4. See, e.g., Lee Epstein et al., Ideological Drift Among Supreme Court Justices: Who, When, and How Important?, 101 Nw. U. L. REv. 1483, 1487-93 (2007) (discussing assumption in debate surrounding confirmations that nominees' ideology will remain similar during their service on the Court); P.S. Ruckman, Jr., The Supreme Court, Critical Nominations, and the Senate Confirmation Process, 55 J. POL. 793, 797-98 (1993) (analyzing the low confirmation rate for nominations that risk shifting the political balance of power on the Court); Jeffrey Segal, Senate Confirmation of Supreme Court Justices: Partisan and Institutional Politics, 49 J. POL. 998, 1000-02, 1012 (1987) (mapping through empirical analysis the factors affecting confirmation, such as Senate partisanship, lame duck status of the President, and strategic decision making); Jeffrey A. Segal et al., A Spatial Model of Roll Call Voting: Senators, Constituents, Presidents, and Interest Groups in Supreme Court Confirmations, 36 AM. J. POL. Sci. 96, 96 (1992) (examining the effect of factors such as ideology of Senators and their constituents, qualifications of the nominee, presidential popularity, and interest group activity on Supreme Court nominations).
} 
of answering discrete research questions. ${ }^{5} \quad$ The lack of a broad empirical foundation in this area is surprising, particularly given the value such work would have to the emerging field of positive constitutional scholarship. Scholars working in this growing area, such as Larry Kramer, Barry Friedman and Neil Siegel, are striving to create a realistic, empirically grounded understanding of the dynamic relationship between public opinion and constitutional development $-\mathrm{a}$ relationship that is on vivid display at Supreme Court confirmation hearings. Scholarship among these authors varies. Kramer, for example, argues that the public should reassert control over constitutional meaning through "popular constitutionalism." $\quad$ Friedman in turn hypothesizes that constitutional development already tracks public opinion over time, while Siegel argues that individual justices play a significant role in shaping our constitutional values. ${ }^{8}$ Despite their differences,

5. Margaret Williams and Lawrence Baum, for example, explored to what extent the substantive differences in terms of the questions posed to nominees are attributable to Bork's failed confirmation by coding all post-1953 hearings by the length and type of question. See Margaret Williams \& Lawrence Baum, Questioning Judges About Their Decisions: Supreme Court Nominees Before the Senate Judiciary Committee, 90 JUDICATURE $73,76-78$ (2006). They provide evidence that both the length of senatorial questions and the number of questions focusing on the nominee's prior judicial record have increased. Id. Professors Guliuzza, Reagan and Barrett undertook a project similar to that of Williams and Baum. See Frank Guliuzza III et al., The Senate Judiciary Committee and Supreme Court Nominees: Measuring the Dynamics of Confirmation Criteria, 56 J. POL. 773, 774 (1994). They coded confirmation hearing transcripts for what they called "constitutional commentaries" by categorizing senatorial questions as involving "character," "competency" or "constitutionalism." Id. They determined that Bork was not asked more questions about constitutionalism than were other nominees, although he was asked more questions about character. $I d$. at 775-76. They also concluded that post-Bork and pre-Bork questioning patterns were more similar to each other than they were to the patterns seen at Bork's confirmation hearing. Id. at 785. Finally, Professors Czarnezki, Ford, and Ringhand used nominee hearing statements to ascertain each nominee's commitment to stare decisis, originalism as an interpretive method, and the protection of criminal defendants, and then compared those commitment levels to decisions that the nominees rendered once on the bench. See Jason J. Czarnezki, William K. Ford \& Lori A. Ringhand, An Empirical Analysis of the Confirmation Hearings of the Justices of the Rehnquist Natural Court, 24 CONST. COMmENT. 127, 130 (2007). This research indicated that the statements about originalism and stare decisis had little correlation with subsequent rulings, while statements about the protection of criminal defendants had some predictive value. Id. at 158. Professor Ringhand followed up on this project with an article examining how often nominees answer questions about particular named cases. See generally Lori A. Ringhand, "I'm Sorry, I Can't Answer That": Positive Scholarship and the Supreme Court Confirmation Process, 10 U. PA. J. ConsT. L. 331 (2008).

6. Larry D. Kramer, The People Themselves: Popular Constitutionalism and JUDICIAL REVIEW 7-8 (2004).

7. Barky friedman, The Will of the People: How Public Opinion Has INFLUENCED THE SUPREME COURT AND SHAPED THE MEANING OF THE CONSTITUTION 17, $367-68(2009)$.

8. Neil S. Siegel, A Coase Theorem for Constitutional Theory, 5 (Duke Law 
however, each of these scholars-and many others working in this area-would benefit from an empirically grounded understanding of how the confirmation process contributes to the interplay of public opinion and constitutional law.

Empirical information quantifying what actually happens at the confirmation hearings is also useful to scholars who advocate changing the process. Whether the confirmation process is or is not working properly, and how it should be fixed if it is not, has been the subject of endless legal, political, and popular debate. Much of this angst is framed, explicitly or implicitly, by a yearning for a bygone erausually thought to be sometime before Robert Bork's failed 1987 hearing-when confirmations were believed to have been more civilized affairs, rather than the partisan ruckus they are seen as today. ${ }^{9}$ This belief that the process has changed-and changed for the worse-has led to a chorus of calls for reform. Some reformers propose that senatorial questioning stay clear of substantive issue areas and be limited to inquiries regarding a nominee's "judicial philosophy."10 Others have gone the opposite direction, advocating more robust and wide-reaching exchanges between the senators and the nominees. ${ }^{11}$ Still others have called for dramatic changes, such as the imposition of supermajority rules on Supreme Court confirmations, ${ }^{12}$ and even for the abolition of the confirmation process entirely. ${ }^{13}$

These reform proposals, like the growing body of positive constitutional scholarship discussed above, clearly would benefit from

Scholarship Repository, Working Paper No. 27, 2010), available at http: //scholarship.law.duke.edu/working_papers/27.

9. For a review of the literature in this area, see generally Jeff Yates \& William Gillespie, Supreme Court Power Play: Assessing the Appropriate Role of the Senate in the Confirmation Process, 58 WASH. \& LEE L. REV. 1053, 1056-57, 1065-69 (2001).

10. See Robert F. Nagel, Advice, Consent, and Influence, 84 Nw. U. L. REV. 858, 863 (1990) (discussing the argument that confirmation questioning should be limited to "responsible ideological review" because excessive Senate participation in judicial selection damages the public's perception of the Court's independence).

11. See Robert Post \& Reva Siegel, Questioning Justice: Law and Politics in Judicial Confirmation Hearings, 115 YALE L.J. POCKET PART 38, 38 (2006), http: //www.thepocketpart.org/ylj-online/supreme-court/27-questioning-justice-law-andpolitics-in-judicial-confirmation-hearings (proposing that Senators ask Supreme Court nominees how they would have voted in cases that have already been decided in order to obtain information without compromising the autonomy of the courts).

12. See John O. McGinnis \& Michael B. Rappaport, Supermajority Rules and the Judicial Confirmation Process, 26 CARDOZO L. REv. 543, 571 (2005) (concluding that a supermajority confirmation process would be appropriate because the Supreme Court can create new constitutional norms and because the small number of justices creates a greater danger of political imbalance in the Court's composition).

13. See Stephen Choi \& Mitu Gulati, A Toumament of Judges?, 92 CAl.IF. L. REv. 299, 300 (2004) (recommending a "Tournament of Judges" where elite federal judges compete for a promotion to the Supreme Court). 
empirical data quantifying what actually happens at Supreme Court confirmation hearings. Empirical work in both of these areas, however, has been stymied by a lack of basic data. What do the senators ask about and what do the nominees talk about? Do these things vary depending on partisan affiliations of the senators and nominees? Do they vary depending on the race or gender of the nominee? Have they changed over time?

Until now, scholars working in these areas have had no comprehensive empirical information with which to answer questions such as these. The Supreme Court Confirmation Hearings Database introduced here remedies this situation. Its content analyzes and codes every senatorial question asked and every nominee response given at every open public hearing held by the Senate Judiciary Committee at which a nominee for the Supreme Court testified. In introducing the database, we also present a description of the patterns underlying the dialogue that transpires at the hearings: we determine whether the quantity and type of questions asked of nominees has changed over the years, which issues have generated the most discussion at the hearings, whether the issues discussed vary depending on the party of the appointing president and that of the questioning senator, and whether different issues are presented to female and minority nominees.

Our findings are wide-ranging. Some simply provide empirical validation of conventional wisdom about the hearings (the hearings have, for example, gotten longer). Others challenge that wisdom: the Bork hearing is less of an outlier in several ways than is frequently assumed, and abortion has not dominated the dialogue between the senators and the nominees. We also present findings that will help scholars tease out the complex mechanisms through which the confirmation process connects public opinion to constitutional law. For example, we find that there is substantial variation over time in the issues discussed at the hearings, and that there are notable disparities in the issues addressed by Democratic versus Republican senators. Finally, we present evidence that speaks directly to the fairness of the process itself: for example, we find that women and minority nominees face a significantly different hearing environment than do white male nominees.

This paper has three parts. Part I provides some background on the Senate confirmation hearings and describes the new data introduced here. Part II analyzes that data and presents our findings. Part III sets forth some tentative conclusions about what the data examined in Part II tell us about the confirmation process, and 
discusses how future research can build on the empirical foundation we establish with this work.

\section{THE SUPREME COURT CONFIRMATION HEARINGS DATABASE}

Article 2, Section 2 of the United States Constitution states that the President, with the advice and consent of the Senate, has the power to appoint justices to the Supreme Court of the United States. ${ }^{14}$ To assist in its part of this process, the Senate in 1816 established the Committee on the Judiciary as a standing committee. ${ }^{15}$ For the first hundred years or so of its history, the Committee did its work quietly: it discussed the nominees in private, did not ask them to appear in person, and rarely took public testimony about them. ${ }^{16}$ This changed in 1925, when nominee Harlan Stone, at the request of President Calvin Coolidge, took the unprecedented step of agreeing to appear before the Committee. ${ }^{17}$ Stone's appearance was limited, however, to defending himself against charges (stemming from the Teapot Dome scandal) involving his earlier work as Attorney General. ${ }^{18}$

In 1939, Felix Frankfurter became the first nominee to take unrestricted questions in an open, transcribed, public hearing. ${ }^{19}$ Between Frankfurter's hearing in 1939 and John Harlan's testimony in 1955, nominees appeared only intermittently. ${ }^{20}$ Some notable jurists nominated in this time frame-such as Chief Justice Earl Warren-did not appear. ${ }^{21}$ Since 1955, however, every Supreme Court nominee other than those whose names were withdrawn before hearings began (e.g., Douglas Ginsburg and Harriet Miers) has appeared and testified before the Committee. ${ }^{22}$

The dataset introduced in this paper includes every hearing since 1939 at which a nominee appeared to testify. Nominees who underwent separate confirmation hearings for an associate justice and then a chief justice nomination are coded separately for each

14. U.S. CONST. art. II, $\S 2$, cl. 2.

15. History of the Senate Committee on the Judiciary, U.S. SENATE COMM. ON THE JUDICIARY, http: //judiciary.senate.gov/about/history/index.cfm (last visited Nov. $13,2010)$.

16. Id.

17. Id.

18. Id.

19. See infra Appendix A (listing every instance where a nominee has appeared personally after Frankfurter pioneered the practice in 1939).

20. See id. (demonstrating that only one nominee appeared before the Committee during this time).

21. See id. Chief Justice Earl Warren was appointed by President Eisenhower and

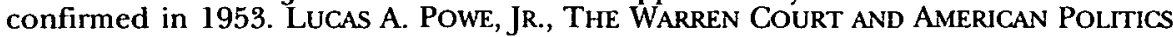
24, 27 (2000).

22. See infra Appendix A. 
appearance. The dataset also includes nominees who appeared to testify but were not confirmed (e.g., Robert Bork and Nixon nominees Harrold Carswell and Clement Haynsworth). It does not, however, include the portion of the Clarence Thomas hearing that was re-opened solely for the purposes of taking testimony regarding the accusations of sexual harassment made by law professor Anita Hill. Nominees included in the dataset, along with their appointing president and confirmation outcome, are listed in Appendix A.

When possible, the data have been collected from the official Senate Judiciary Committee transcripts as available either online at the Senate's webpage, ${ }^{23}$ or in The Supreme Court of the United Sates: Hearings and Reports on Successful and Unsuccessful Nominations of Supreme Court Justices by the Senate Judiciary Committee 1916-1975. ${ }^{24}$ The Sotomayor hearing was coded from the transcript available at the New York Times webpage. ${ }^{25}$

The unit of analysis in the dataset is a change of speaker, meaning that a new observation begins whenever the speaker changes. For example, the following discussion between Sonia Sotomayor and Senator Hatch represents two observations, one for Hatch and one for Sotomayor:

SEN. HATCH: All right. In what way does the Court's observation that the Second Amendment codified the preexisting, fundamental right to bear arms affect your conclusion that the Second Amendment does not protect a fundamental right?

JUDGE SOTOMAYOR: My conclusion in the Maloney case or in the U.S. Sanchez-Villar was based on precedence [sic] and the holding of precedence [sic] that the Second Circuit did not apply to the states.

Each comment is coded by both its primary issue and any relevant subissues. Senatorial comments and nominee comments are coded separately and therefore need not (although usually do) involve the same issue and subissue(s). A single unit of analysis can have only

23. Nomination Hearings for Sitting Supreme Court Justices, U.S. SENATE, http: //www.senate.gov/pagelayout/reference/one_item_and_teasers/Supreme_Court_N omination_Hearings.htm (last visited Nov. 13, 2010).

24. THE SUPREME COURT OF THE UNITED STATES: HEARINGS AND REPORTS ON SUCCESSFUL AND UNSUCCESSFUl NOMINATIONS OF SUPREME COURT JUSTICES BY THE SENATE JudiClARY COMMITTEE, 1916-1975 (Roy M. Merksy \& J. Myron Jacobstein eds., 2007).

25. The transcripts used to code this study are available at

http:/ / www.nytimes.com by searching "Sotomayor confirmation hearings."

26. Confirmation Hearing on the Nomination of Hon. Sonia Sotomayor, to $\mathrm{Be}$ an Associate Justice of the Supreme Court of the United States: Before the S. Comm. on the Judiciary, 111 th Cong. 87 (2009). 
one issue, but may have multiple subissues. So, for example, a senatorial comment asking about the nominee's opinion on race and gender discrimination would have one issue ("civil rights") and two subissue codes ("race" and "gender"). Subissue codes are unique to their issue in that the same subissue does not appear in multiple issue codes.

The issue and subissue codes used in the project are based on the Policy Agendas Project, ${ }^{27}$ with some confirmation-specific codes added. The issue codes include areas such as "civil rights," "criminal justice," and "judicial philosophy." Subissues include such topics as "gender discrimination," "racial discrimination," and "religion: free exercise" (in the civil rights issue area); "Miranda warnings" and "white collar crime" (in the criminal justice issue area); and "precedent" and "original intent" (in the judicial philosophy issue area). We also have created an issue code for "chatter." The purpose of this code is to capture non-substantive discussion, such as the scheduling of breaks and other social chitchat that occurs frequently among the senators and nominees. Chatter also includes discussions of the nominee's education, family and background. A complete list of the issues and subissues coded is available in Appendix B.

Each comment is also coded for identification variables, such as the name of the questioning senator, the questioning senator's political party, the party holding majority control in the Senate at the time of the hearing, and the party of the nominating president. Political party variables are coded as of the date of the hearing. So, for example, a senator such as Arlen Specter, who served on the Judiciary Committee as both a Republican and a Democrat, will appear in the data as both a Republican and a Democrat, with his party affiliation depending on the date of the hearing being coded.

We subjected the data to extensive reliability testing. The data are, overall, very reliable. The average agreement rate between coders for all variables is $91.2 \%$ and the average kappa is 0.89 , which is "almost perfect" by one commonly used metric. ${ }^{28}$ While some variables exhibit weaker intercoder agreement, no variable does worse than "moderate" in terms of kappa and almost all exhibit "substantial" to "almost perfect" intercoder agreement rates. A full reliability analysis report is available in Appendix C.

27. Frank Baumgartner \& Bryan Jones, Topic Codebook, POLICY AGENDAS PROJECT, http: //www.policyagendas.org/page/topic-codebook (last visited Nov. 13, 2010).

28. See J. Richard Landis \& Gary G. Koch, The Measurement of Observer Agreement for Categorical Data, 33 BIOMETRICS 159, 165 (1977). 


\section{DATA ANALYSIS}

This section analyzes the data described above. Specifically, we examine four aspects of Supreme Court confirmation hearings: the quantity of comments over time; (2) the issues and subissues addressed, and the extent to which those issue areas and subissues have changed over time; (3) the significance of the party affiliation of the appointing president and of the questioning senators in the topics addressed at the hearings; and (4) whether the issues raised at the hearings vary with respect to nominee race and gender.

Our findings are notable. First, we find that the number of comments at the hearings has increased, but that this increase, contrary to common assertions, ${ }^{29}$ did not begin with the Bork hearings. Second, we find that the issue areas addressed at the hearings have varied over time, but that discussions of civil rights issues have been dominant since 1970. We also find that the topics addressed within the civil rights area itself have changed over time; most notably, comments about racial discrimination have ebbed while comments about gender and sexual orientation discrimination have increased. Each of these findings, as we explain in Part III, has implications for our understanding of how the confirmation hearings help to shape the development of constitutional law.

We also make additional findings that will facilitate a richer appreciation of the confirmation process. We find, for example, that there is significant variation in the questions asked by Democratic and Republican senators: Democrats ask more questions about criminal justice issues, while Republicans dominate questioning about judicial philosophy, statutory interpretation, and national security. We also find that abortion has not played as important a role in the hearings as is often assumed, even after accounting for the fact that Roe $v$. Wade $e^{30}$ was not decided until quite late in the time period covered by the dataset. Finally-and perhaps most importantly-we find that women and minority nominees face a different hearing environment than do white male nominees. They are asked more substantive questions overall, and more questions about their judicial philosophy. Minority nominees also are asked more questions about criminal justice.

29. See, e.g., Stephen J. Wermeil, Confirming the Constitution: The Role of the Senate Judiciary Committee, 56 LAW \& CONTEMP. PROBS. 121, 130-31 (1993) (asserting that the transformative nature of Bork's lengthy and voluminous hearing process established a "new norm" for confirmation hearings).

30. 410 U.S. 113 (1973). 


\section{A. The Quantity of Comments Over Time}

Figure 1 reports the number of comments made by nominees and senators at Senate Judiciary Committee confirmation hearings from 1939 to 2009 . The nominees are aligned along the $x$-axis, while the $y$ axis reports the total number of comments made by nominees (the dashed line) and senators (the solid line). This figure reveals two significant things. First, note the strong association between the number of comments made by nominees and senators. Using the hearing as the unit of analysis, the correlation between the number of comments made by nominees and senators is $0.992(p<0.001)$. As such, it is evident that our data reflect the fact that confirmation hearings take place in a question and answer format, with senators traditionally moving first by asking questions, followed by the nominees responding in turn.

Second, the number of comments made by both nominees and senators has increased rather dramatically over time. For example, from 1939-1981, the average number of comments made by nominees was 181, while the average number of comments made by senators was 253. Since Rehnquist's Chief Justice hearing in 1986, however, the average number of comments made by nominees was 749 and the average number of comments made by senators was 987 .

While the Bork hearings represent the greatest number of comments, with 1587 statements made by Bork and 1931 remarks made by senators, it is notable that the increase in the number of statements made at the hearings began not with Bork, but with Rehnquist's nomination for Chief Justice in 1986. During that hearing, Rehnquist made 727 statements, while senators contributed 1135 questions and comments. Thus, while the Bork hearing is certainly an outlier in terms of the number of statements made, Bork's nomination does not represent the point at which the number of comments made at confirmation hearings saw its most radical transformation. Rather, Figure 1 reveals that the increase in the number of comments made at confirmation hearings was initiated at Rehnquist's hearing for the position of Chief Justice. 

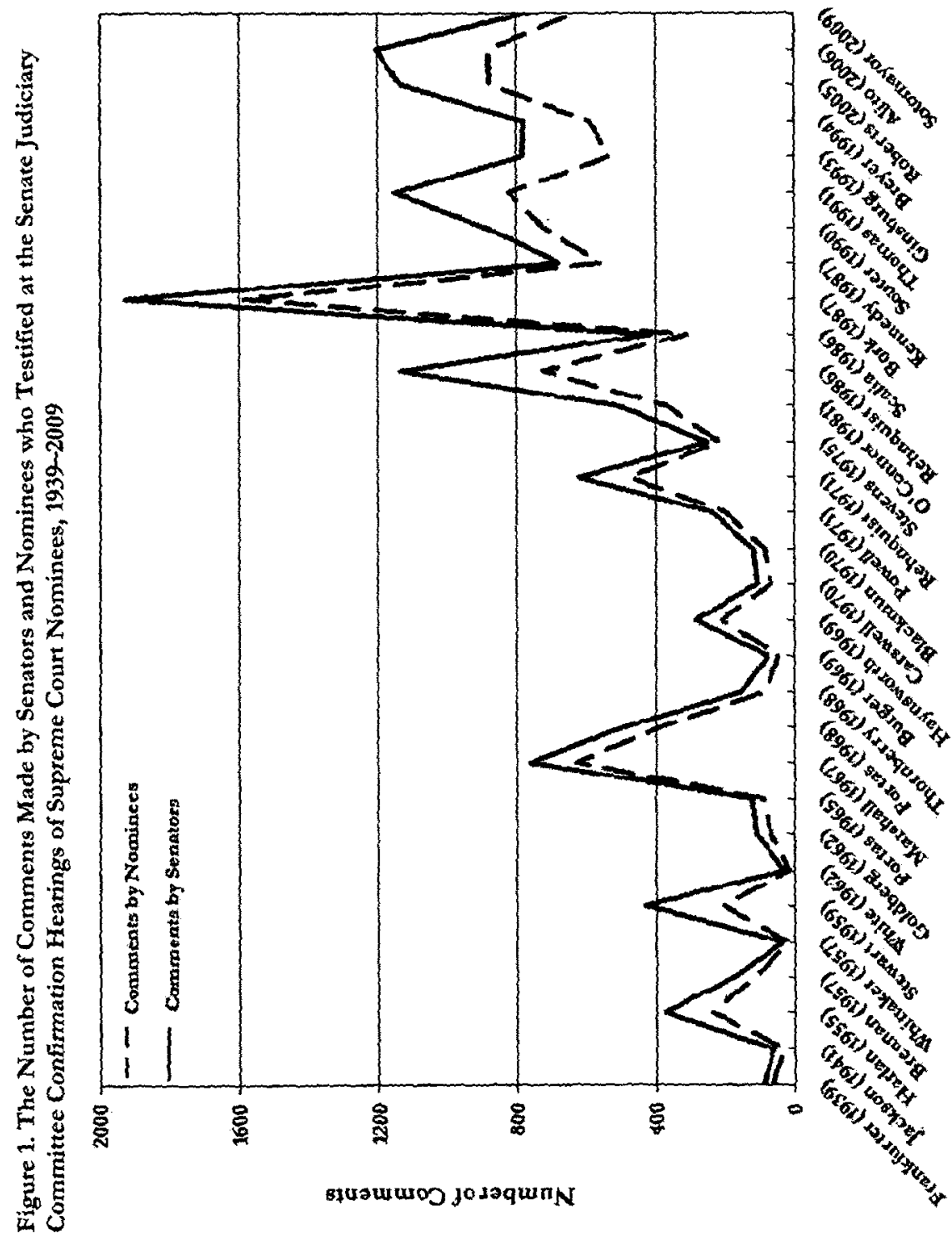
Table 1. The Issues Addressed by Senators and Nominees who Testified at the Senate Judiciary Committee Confirmation Hearings of Supreme Court Nominees, 1939-2009

\begin{tabular}{llll}
\hline Issue & Senators & Nominees & Total \\
\hline Hearing Administration/Chatter & $41.8 \%(6,658)$ & $26.4 \%(3,134)$ & $35.2 \%(9,792)$ \\
Civil Rights & $26.8 \%(4,266)$ & $33.8 \%(4,003)$ & $29.8 \%(8,269)$ \\
Judicial Philosophy & $11.2 \%(1,777)$ & $14.1 \%(1,667)$ & $12.4 \%(3,444)$ \\
Criminal Justice & $7.7 \%(1,231)$ & $9.8 \%(1,161)$ & $8.6 \%(2,392)$ \\
Govemment Operations & $3.3 \%(521)$ & $4.1 \%(485)$ & $3.6 \%(1,006)$ \\
Court Administration & $2.9 \%(466)$ & $3.8 \%(446)$ & $3.3 \%(912)$ \\
Federalism & $1.1 \%(177)$ & $1.5 \%(177)$ & $1.3 \%(354)$ \\
Statutory Interpretation & $0.8 \%(127)$ & $1.1 \%(127)$ & $0.9 \%(254)$ \\
Banking and Finance & $0.8 \%(123)$ & $1.0 \%(120)$ & $0.9 \%(243)$ \\
Labor and Employment & $0.6 \%(98)$ & $0.8 \%(96)$ & $0.7 \%(194)$ \\
Standing/Access to Courts & $0.6 \%(91)$ & $0.7 \%(85)$ & $0.6 \%(176)$ \\
Best/Favorite Justices & $0.4 \%(58)$ & $0.5 \%(58)$ & $0.4 \%(116)$ \\
National Defense & $0.4 \%(59)$ & $0.5 \%(55)$ & $0.4 \%(114)$ \\
Other Issues & $1.7 \%(276)$ & $2.1 \%(247)$ & $1.9 \%(523)$ \\
Totals & $100.1 \%(15,928)$ & $1002 \%(11,861)$ & $100 \%(27,789)$
\end{tabular}

The unit of analysis is the change of speaker. The column entries represent the percentage of comments regarding each issue area. The percentages do not necessarily sum to $100 \%$ due to rounding. The numbers in parentheses indicate the total number of comments pertaining to each issue area. Issue areas representing less than $0.4 \%$ of the column totals are combined into the "Other Issues" category. The data contain information on Supreme Court nominees, both confirmed and unconfirmed, who appeared in front of an open session of the Senate Judiciary Committee since 1939.

\section{B. Issues and Subissues}

Table 1 reports the issues addressed by senators and nominees who appeared before the Senate Judiciary Committee from 1939 to 2009. As this table illustrates, a plurality of comments (35.2\%) at the Senate Judiciary Committee hearings of Supreme Court nominees involve confirmation chatter. The bulk of the chatter category $(57.1 \%)$ is made up of miscellaneous talk among the senators, including nonsubstantive clarifications such as "excuse me," or "could you repeat that," as well as senatorial discussions of scheduling and social chitchat. About a quarter of the chatter category $(24.3 \%)$ involves discussions of the nominees' background and education, while the remainder involves discussion of media coverage of the nominations and pre-hearing coaching. Note that this category does not include senatorial statements posing as questions (a common practice), requests for clarifications that have a substantive component, or single word comments (such as "yes") that carry substantive meaning when considered in context.

Looking at Table 1, it is tempting to note that the members of the Judiciary Committee could cut the number of comments made at the hearings by more than a third simply by engaging in less chatter. We admit to considering making such a suggestion. But two things about the chatter issue area compel us to resist this urge, and to treat the category with more respect. 
First, the largest contributors to the senatorial chatter category are the committee chairs, who make up almost half of all chatter. Although only speculative, our impression as coders is that most of these comments consist of necessary discussions of hearing logistics and other scheduling matters, in addition to the introductory exchanges in which the nominee discusses his or her education and background. Second, as we discuss below, the percentage of chatter at the hearings appears to be leveling off rather than increasing, suggesting that the senators themselves are moving toward viewing their role as a more substantive one. This also assures us that the practice of televising the hearings, which began in 1981 with the O'Connor hearing, ${ }^{31}$ has not increased chatter among the senators.

Table 1 also reveals that three issues have dominated the substance of the hearings: civil rights, judicial philosophy and criminal justice. The most common substantive issue area addressed at the hearings is civil rights. Givil rights dialogue constitutes $26.8 \%$ of all senatorial comments and $33.8 \%$ of all nominee comments contained in the dataset. Taking senatorial and nominee comments together, statements about civil rights thus comprise $29.8 \%$ of all of our observations. Judicial philosophy, which includes comments about methods of constitutional interpretation, the role of the Court, and judicial activism, is a distant second, constituting only $12.4 \%$ of all comments. Criminal justice, including discussions of criminal procedure, capital punishment and juvenile justice, rounds out the top three substantive areas with $8.6 \%$ of the total comments. The remaining issue areas reported in Table 1 are discussed relatively infrequently, with no single issue area representing more than $4 \%$ of commentary.

Table 2 reports the most frequently addressed non-chatter issue area by nominee. This table reveals that civil rights, judicial philosophy, and criminal justice have dominated the hearings not just overall, but since their inception. Civil rights has been the most frequently discussed issue area at all of the hearings since 1971. It was also the most frequently addressed issue area in twenty-one of the thirty-one hearings in the dataset as a whole. Judicial philosophy, in contrast, was the most discussed issue at only four of the hearings, while criminal justice dominated an additional four. Only two hearings, that of Byron White (1962) and Warren Burger (1969) were dominated by issues other than these three: White's hearing focused

31. Michael Comiskey, Not Guilty: The News Media in the Supreme Court Confirmation Process, 15 J.L. \& POL. 1, 29 (1999). 
Table 2. The Most Frequently Addressed Non-Chat ter Issue by Senators and Nominees, per Nominee, who Testified at the Senate Judiciary Committee Confirmation Hearings of Supreme Court Nominees, 1939-2009

\begin{tabular}{|c|c|c|}
\hline \multirow[b]{2}{*}{ Nominee Name (Year) } & \multicolumn{2}{|c|}{ Most Erequently Addressed Issue } \\
\hline & Senators & Nominees \\
\hline Frankfurter (1939) & Civil Rights (24.5\%) & Civil Rights (31.8\%) \\
\hline Jackson (1941) & Criminal Justice (21.9\%) & Criminal Justice $(97.0 \%)$ \\
\hline Harlan (1955) & Judicial Philosophy (15.6\%) & Judicial Philosophy (15.6\%) \\
\hline Breman (1957) & Civil Rights (48.0\%) & Civil Rights $(58.6 \%)$ \\
\hline Whittaker (1957) & Civil Rights (21.6\%) & Civil Rights (21.1\%) \\
\hline Stewart (1959) & Judicial Philosophy (29.7\%) & Judicial Philosophy $(49.0 \%)$ \\
\hline White (1962) & Standing/Access to Courts (25.0\%) & Standing/Access to Courts (42.9\%) \\
\hline Goldberg (1962) & Judicial Philosophy (29.8\%) & Judicial Philosophy (46.4\%) \\
\hline Fortas (1965) & Criminal Justice $(16.9 \%)$ & Criminal Justice $(19.6 \%)$ \\
\hline Marshall (1967) & Criminal Justice (46.7\%) & Criminal Justice $(52.5 \%)$ \\
\hline Fortas (1968) & Criminal Justice (21.4\%) & Criminal Justice $(23.9 \%)$ \\
\hline Thomberry (1968) & Civil Rights (40.4\%) & Civil Rights (58.0\%) \\
\hline Burger (1969) & Judicial Administration (25.6\%) & Judicial Administration (41.7\%) \\
\hline Haynsworth (1969) & Civil Rights (4.9\%) & Civil Rights (6.7\%) \\
\hline Carswell (1970) & Civil Rights (45.1\%) & Civil Rights (49.3\%) \\
\hline Blackmun (1970) & Judicial Philosophy (12.3\%) & Judicial Phílosophy (15.6\%) \\
\hline Powell (1971) & Civil Rights (47.7\%) & Civil Rights $(54.6 \%)$ \\
\hline Rehnquist (1971) & Civil Rights $(31.6 \%)$ & Civil Rights (38.5\%) \\
\hline Stevens (1975) & Civil Rights (22.0\%) & Civil Rights (23.9\%) \\
\hline O'Connor (1981) & Civil Rights (23.5\%) & Civil Rights $(27.9 \%)$ \\
\hline Rehnquist (1986) & Civil Rights (24.3\%) & Civil Rights (33.4\%) \\
\hline Scalia (1986) & Civil Rights (25.2\%) & Civil Rights (31.6\%) \\
\hline Bork (1987) & Civil Rights $(36.9 \%)$ & Civil Rights $(45.2 \%)$ \\
\hline Kennedy (1987) & Civil Rights (24.7\%) & Civil Rights $(28.0 \%)$ \\
\hline Souter $(1990)$ & Civil Rights (29.9\%) & Civil Rights $(36.8 \%)$ \\
\hline Thomas (1991) & Civil Rights $(32.0 \%)$ & Civil Rights (44.9\%) \\
\hline Ginsburg (1993) & Civil Rights (28.6\%) & Civil Rights (39.7\%) \\
\hline Breyer (1994) & Civil Rights (21.5\%) & Civil Rights (272\%) \\
\hline Roberts (2005) & Civil Rights (37.7\%) & Civil Rights $(44.0 \%)$ \\
\hline Alito (2006) & Civil Rights (21.9\%) & Givil Rights $(26.5 \%)$ \\
\hline Sotomayor (2009) & Civil Rights (23.0\%) & Civil Rights (29.5\%) \\
\hline
\end{tabular}

The numbers in parenthesis indicate the percentage of comments represented by the most frequenty addressed issue area. The data contain information on Supreme Court nominees, both confirmed and unconfirmed, who appeared in front of an open session of the Senate Judiciary Committee since 1939.

on issues of standing and access to courts, while Burger's hearing for Chief Justice devoted a substantial amount of attention to issues implicating judicial administration.

While the tables examined above provide a great deal of information regarding the issues discussed in the Senate Judiciary Committee, they do not speak to whether there have been changes over time in the percentages of comments addressing each issue at each hearing. Identifying such temporal changes is key to exploring connections between public opinion (as evidenced through senatorial questioning) and constitutional change. As such, we provide below a more fine-grained analysis of temporal changes within the chatter, civil rights, criminal justice, and judicial philosophy issue areas. We also break down the broad civil rights category and examine temporal changes in several of the subissues included within that issue area. 


\section{Hearing administration and chatter}

Figure 2 presents the percentage of comments regarding hearing administration and chatter made by senators and nominees from 1939 to 2009 . The nominees in this figure, and in those that follow, are arranged along the $\mathrm{x}$-axis, while the $\mathrm{y}$-axis represents the percentage of comments involving hearing administration and chatter. Comments by nominees are indicated by the dashed line, while comments from senators are denoted by the solid line.

As Figure 2 makes clear, there has been substantial temporal variation with respect to the percentage of comments involving hearing administration and chatter. For example, more than $90 \%$ of the comments made by nominees and senators during the Haynsworth (1969) hearing involved chatter. Similarly, about $80 \%$ of the comments proffered by nominees and senators at the Harlan (1955) and Whittaker (1957) hearings were chatter. In more recent years, however, chatter levels dropped. For example, the percentage of chatter from senators prior to 1971 was $46.1 \%$, compared to $40.6 \%$ in the post-1970 era. While this supports commonly made assertions that confirmations hearings used to be more chummy affairs, it also makes clear that senators and nominees have striven to be more substantive in recent hearings, at least in terms of the issue areas they choose to address. Opinions may differ, but we do not rue this development.

\section{Civil rights}

As shown in Figure 3, civil rights has dominated the substantive issue areas covered at the hearings overall, and has done so with particular force since 1970. This figure plots the percentage of comments made regarding civil rights from 1939 to 2009. While there was notable variation in the pre-1970 era, with the Jackson (1941) and White (1962) hearings containing no discussion of civil rights, it is apparent that civil rights has become an essential part of the confirmation hearings. In fact, since 1971, interrogation by senators regarding a nominee's views of the pressing civil rights issues of the day has never represented less than $20 \%$ of all questions asked at the hearings.

The dominance of civil rights comments is particularly notable given that the number of comments likely to have been motivated by civil rights concerns may be somewhat understated in the data. It is not unusual for senators to present substantive concerns about an issue area in comments that are, under our coding rules, coded as "judicial philosophy." This is particularly so in the civil rights issue 


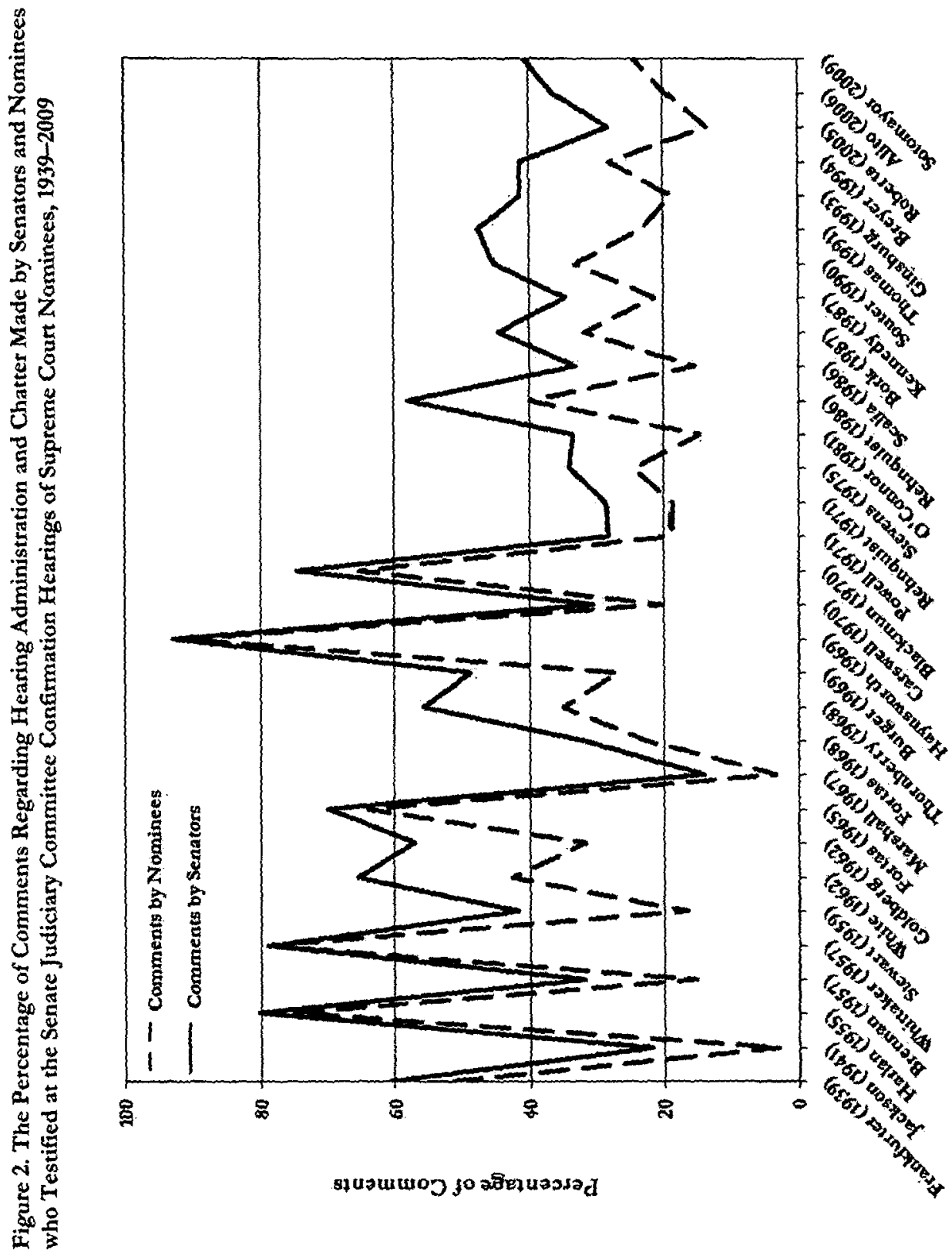




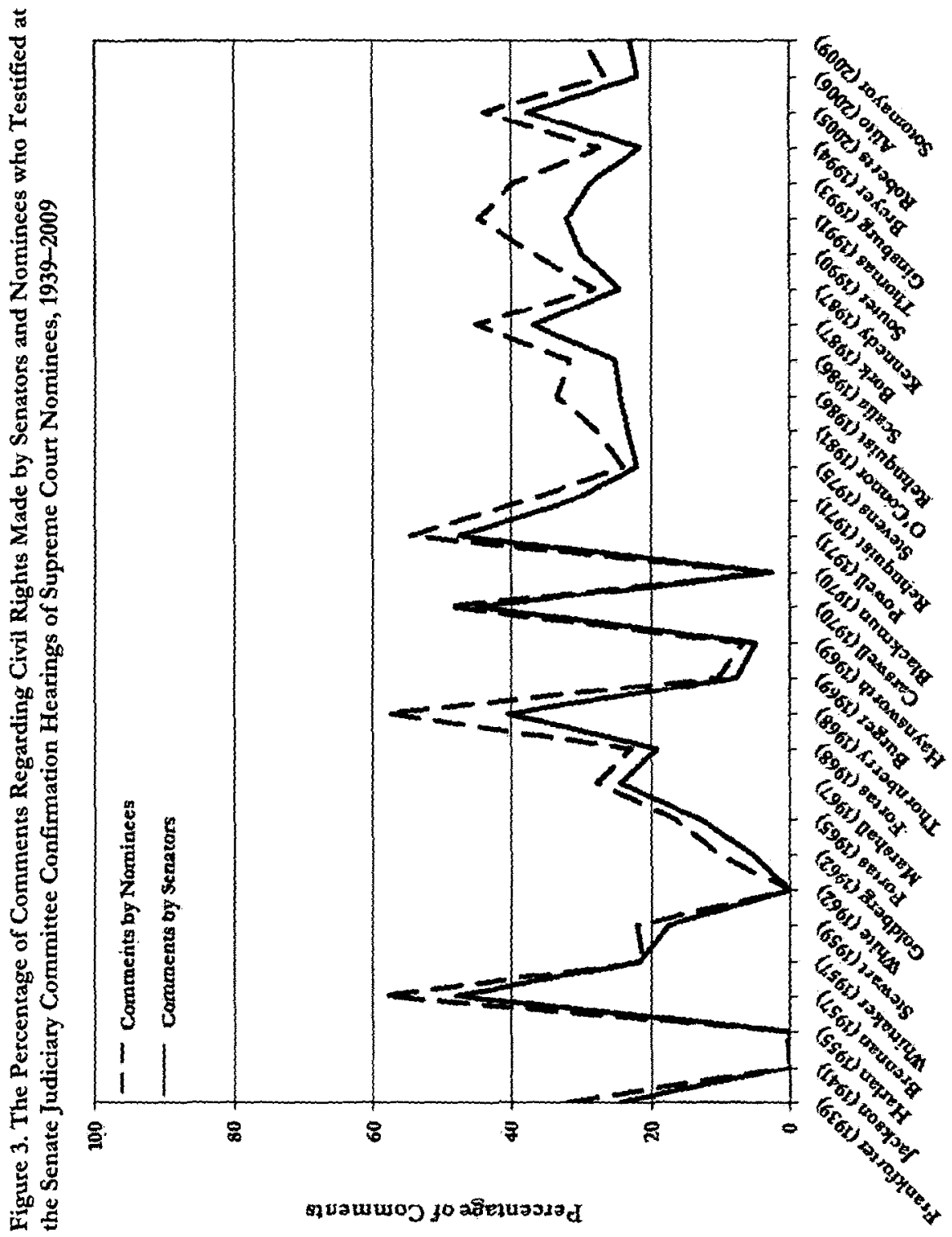


area. The most obvious example of this is the 1959 hearing of Potter Stewart. Stewart was nominated just five years after the Court's landmark Brown $v$. Board of Education ${ }^{32}$ decision and his hearing was held at a time in which the federal courts were still sorting out how aggressively they would oversee school desegregation. In this political environment, Stewart was bombarded with questions from Southern Democrats about the dangers of judges replacing "the law" with their "personal notions" of good policy, the problem of judges trying to "amend" the Constitution, and the importance of stare decisis. ${ }^{33}$ It seems unlikely that these comments, coming at the time and from the senators that they did, were unrelated to Brown. Indeed, the Senators at the Stewart hearing often made the connection with Brown explicit. Consider, for example, the following comment by Senator Ervin of North Carolina:

I think the Brown v. the Board of Education [sic] was a most unfortunate decision from the standpoint of law, Constitutional law in the United States . . . . In the first place, the Court said that it couldn't turn the clock back to 1868 when the Amendment was ratified or even to 1869 when Plessy $v$. Ferguson was decided, and yet since Constitutional provisions are to be interpreted to ascertain and give effect to the intention of the people who drew them and approved them, that is exactly what the Supreme Court should have done. They should have turned the clock back to 1868 when the Amendment was ratified. ${ }^{34}$

Often, however, the senators did not link their opinions about Brown so directly to their comments about judicial philosophy. Consider this question by Senator Johnston of South Carolina: "Are you going to be what you call a 'creative judge' or are you going to to [sic] follow the law and the precedent?"

Under our coding rules, Senator Ervin's comment would be coded as involving civil rights, while Senator Johnston's would be coded as one of judicial philosophy. This is so despite the fact that Senator Johnston's statement is highly likely to have been as motivated by Brown (which he discussed shortly after the exchange in which the above comment appears) as was Senator Ervin's. We cannot presume to accurately perceive senatorial motivations, however, so comments such as Johnston's which are not articulated as civil rights issues are

32. 347 U.S. 483 (1954).

33. See, e.g., Nomination of Potter Stewart to Be Associate Justice of the Supreme Court of the United States Before the S. Comm. on the Judiciary, 86th Cong. 115, 123-24 (1959) (question by Sen. Samuel Ervin, Member, S. Comm. on the Judiciary).

34. Id. at 124.

35. Id. at 20-21. 
Table 3. The Civil Rights Issues Addressed by Senators and Nominees who Testified at the Senate Judiciary Committee Confirmation Hearings of Supreme Court Nominees, 1939-2009

\begin{tabular}{llll}
\hline Issue & Senators & Nominees & Total \\
\hline Racial Discrimination & $23.5 \%(1,001)$ & $22.4 \%(897)$ & $23.0 \%(1,898)$ \\
Freedom of Speech/Religion & $16.1 \%(686)$ & $16.9 \%(676)$ & $16.5 \%(1,362)$ \\
Right to Privacy (non-abortion) & $14.7 \%(626)$ & $14.7 \%(590)$ & $14.7 \%(1,216)$ \\
Gender/Sexual Orientation Discrimination & $12.7 \%(542)$ & $12.7 \%(507)$ & $12.7 \%(1,049)$ \\
Abortion Rights & $12.5 \%(534)$ & $11.9 \%(477)$ & $12.2 \%(1,011)$ \\
Voting Rights & $9.1 \%(388)$ & $9.2 \%(369)$ & $9.2 \%(757)$ \\
Ant-Grovernment Activivies & $4.1 \%(176)$ & $3.8 \%(153)$ & $4.0 \%(329)$ \\
Right to Keep and Bear Arms & $1.6 \%(70)$ & $1.8 \%(72)$ & $1.7 \%(142)$ \\
Handicap/Disease Discrimination & $1.4 \%(59)$ & $1.2 \%(49)$ & $1.3 \%(108)$ \\
Age Discrimination & $0.5 \%(22)$ & $0.5 \%(21)$ & $0.5 \%(43)$ \\
Other Civil Rights Issues & $11.8 \%(505)$ & $12.4 \%(495)$ & $12.1 \%(1,000)$ \\
Totals & $108 \%(4,609)$ & $107.5 \%(4,306)$ & $107.9 \%(8,915)$
\end{tabular}

The unit of analysis is the change of speaker. The column entries represent the percentage of comments regarding each civil rights issue area. The percentages exceed $100 \%$ because a single comment by a senator or nominee can fall within multiple civil rights issue areas (e.g., abortion and freedom of speech). The numbers in parentheses indicate the total number of comments pertaining to each issue area falling within the civil rights caregory. Miscellaneous civil rights issue areas and civil rights issue areas representing less than $0.4 \%$ of the column totals are combined into the "Other Civil Rights Issues" category. The number of comments exceeds the number of civil rights comments reported in Table 1 because a single statement by a senator or nominee can touch on multiple civil rights issues. The data contain information on Supreme Court nominees, both confirmed and unconfirmed, who appeared in front of an open session of the Senate Judiciary Committee since 1939.

coded in our data as raising issues of judicial philosophy rather than civil rights. ${ }^{36}$ Thus, the actual number of comments motivated in fact by concerns about civil rights may be higher than is reflected in our findings.

Regardless, civil rights issues clearly have, even under our conservative coding regime, dominated the hearings at which the nominees have testified. Civil rights, however, is a broad issue area. It includes, among other things, race, gender, age and disability discrimination; speech and religious freedom; and the right to keep and bear arms. To more fully understand the role this issue area has played in the hearings, it is therefore worth examining the prevalence and distribution of the subissues within it.

As Table 3 illustrates, statements involving discrimination constitute a plurality of comments within the civil rights issue area. Specifically, discussions of racial discrimination comprise $23 \%$ of civil rights comments. Gender and sexual orientation discrimination constitute an additional $12.7 \%$, while age and disability discrimination add $1.8 \%$. Combined, dialogue involving

36. Sonia Sotomayor's hearing provides additional examples of this. Many of the comments from her hearing coded as "judicial philosophy" involved whether she would allow her personal experiences to influence how she decided cases. To those familiar with her nomination, such comments likely appear to have been based on concerns of racial bias allegedly revealed in a series of speeches Sotomayor had given before her nomination. See generally Sonia Sotomayor, Judge, Court of Appeals for the Second Circuit, A Latina Judge's Voice (Oct. 26, 2001) (transcript available at http: //www.law.berkeley.edu/4982.htm). 
discrimination thus constitutes $37.5 \%$ of the comments within the civil rights issue area. Freedom of speech/religion is the next most commonly discussed civil rights subissue, followed by non-abortion privacy and, at only $12.2 \%$ of the issue area, abortion rights. Dialogue implicating voting rights represent $9.2 \%$ of the civil rights category, while treatments of anti-government activities constitute $4 \%$ this issue. Debates concerning the Second Amendment, first appearing at O'Connor's hearing in 1981 and constituting $8.8 \%$ of all dialogue at the Sotomayor hearing in 2009, make up only $1.7 \%$ of civil rights discourse. Below, we provide a detailed treatment of the five most frequently occurring subissues involving civil rights.

\section{a. Race and gender/sexual orientation discrimination}

The prevalence of racial discrimination comments is not surprising, given the importance of racial justice issues within constitutional law, as well as the fact that all but two of the hearings contained in the dataset occurred after the Supreme Court's Brown decision. ${ }^{37}$ Conflicts about racial issues, so prevalent in society throughout much of the time period covered in the dataset, plainly infiltrated the confirmation hearings.

Interestingly, however, the dominance of race discrimination comments may be waning. While remaining the most frequently mentioned subissue within the civil rights issue area, the percentage of civil rights comments involving racial discrimination has actually declined since the mid-1980s. Figure 4 plots the percentage of civil rights commentary involving racial discrimination. As this figure makes clear, discussions of racial discrimination dominated the civil rights category for several nominees, most notably Harlan (1955), Stewart (1959), and Haynsworth (1969), but questions regarding racial discrimination have tapered off since the mid-1980s.

This decline may well reflect a mid-1980s "constitutional consensus" that the Constitution proscribes (and allows Congress to penalize) intentional discrimination against racial minorities. ${ }^{38}$ A comparison of Rehnquist's 1986 Chief Justice hearing, Bork's failed 1987 hearing, and Kennedy's subsequent 1987 hearing illustrates this point.

37. A new paper speculates that nominee testimony became the norm after 1955 precisely because of Brown. Dion Fargabis \& Justin Wedeking, "No Hints, No Forecasts, No Previews": An Empirical Analysis of Supreme Court Nominee Candor From Harlan to Kagan, 2011 LAW \& SOC. REV. (forthcoming 2011), available at http://www.uky.edu/ -jpwede2/NoHints_Revised.pdf.

38. See Ringhand, supra note 5 , at $34 \overline{5}$ (asserting that Brown is "surely among the most settled of our settled cases"). 

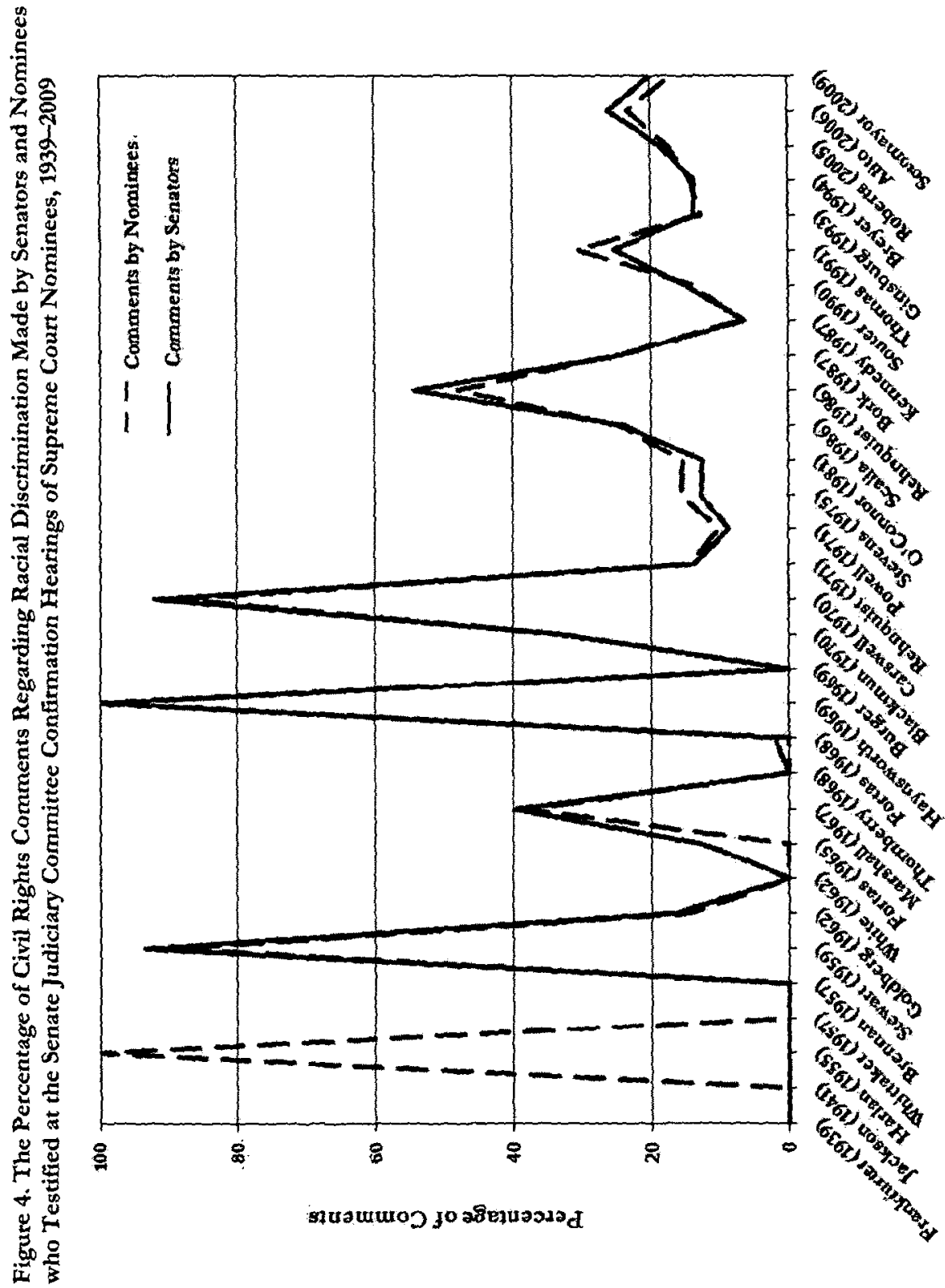
Rehnquist, the first of these nominees to face the Judiciary Committee, was confirmed as Chief Justice, but only after repeatedly disavowing a memo written when he was a law clerk that appeared to endorse Plessy $v$. Ferguson ${ }^{39}$ (the 1896 case that validated segregation and the "separate but equal" doctrine).$^{40}$ A year later, in 1987, Robert Bork told the Committee that Brown (which overturned Plessy) had been correctly decided, but appeared ambivalent about the constitutionality of poll taxes, racial covenants, and landmark civil rights legislation. ${ }^{41}$ Bork was not confirmed. Justice Kennedy, nominated for the seat Bork failed to acquire, affirmed both Brown and The Civil Rights Act of 1964, and spoke strongly in favor of the federal government's power to prohibit racial discrimination. ${ }^{42}$ Since Kennedy, no nominee has seriously refuted Brown or the legitimacy of federal anti-discrimination laws, and racial discrimination, perhaps consequently, has become less dominant in the hearings.

As comments regarding racial discrimination declined, comments about gender and sexual orientation discrimination arrived to fill the gap. As shown above in Table 3, discussions about gender and sexual orientation discrimination constitute $12.7 \%$ of the civil rights comments in the dataset, making this the fourth most frequently commented upon civil rights subissue in the dataset. As shown in Figure 5, however, all of the activity in this area has occurred since 1970, with most of it coming after 1975.

The emergence of these issues in the 1970s is not surprising. The 1970 s were pivotal for both the women's rights and the gay rights movements. The National Organization of Women marched on Washington, the Equal Rights Amendment was re-introduced in Congress, and Gloria Steinman founded Ms. Magazine. ${ }^{43}$ Gay rights activists also gained momentum in the 1970s. The Stonewall Riot, widely considered the birth of the gay rights movement, occurred in New York City in $1969 .{ }^{44}$ The country's first gay pride parades,

39. 163 U.S. 537 (1896).

40. Nomination of Justice William Hubbs Rehnquist to be Chief Justice of the United States Before the S. Comm. on the Judiciary, 99th Cong. 161-62 (1987).

41. The Nomination of Robert H. Bork to be Associate Justice of the Supreme Court of the United States Before the S. Comm. on the Judiciary, 100th Cong. 152, 155, 253, 348 (1989).

42. The Nomination of Anthony M. Kennedy to be Associate Justice of the Supreme Court of the United States Before the S. Comm. on the Judiciary, 100th Cong. 149, 151-52, 182-83 (1989).

43. See Barbara Burrell, Women and Political Participation: A Reference HANDBOOK 62-63, 203 (2004) (providing a history of the women's political movement); DOROTHY MCBRIDE-STETSON, WOMEN'S RIGHTS IN THE USA: POLICY DEBATES AND GENDER ROLES 36-37 (3d ed. 2004) (discussing NOW's campaign for passage of the Equal Rights Amendment).

44. David GaRTER, StONEWAll: The Riots that SPaRkEd the Gay Revolution 1 


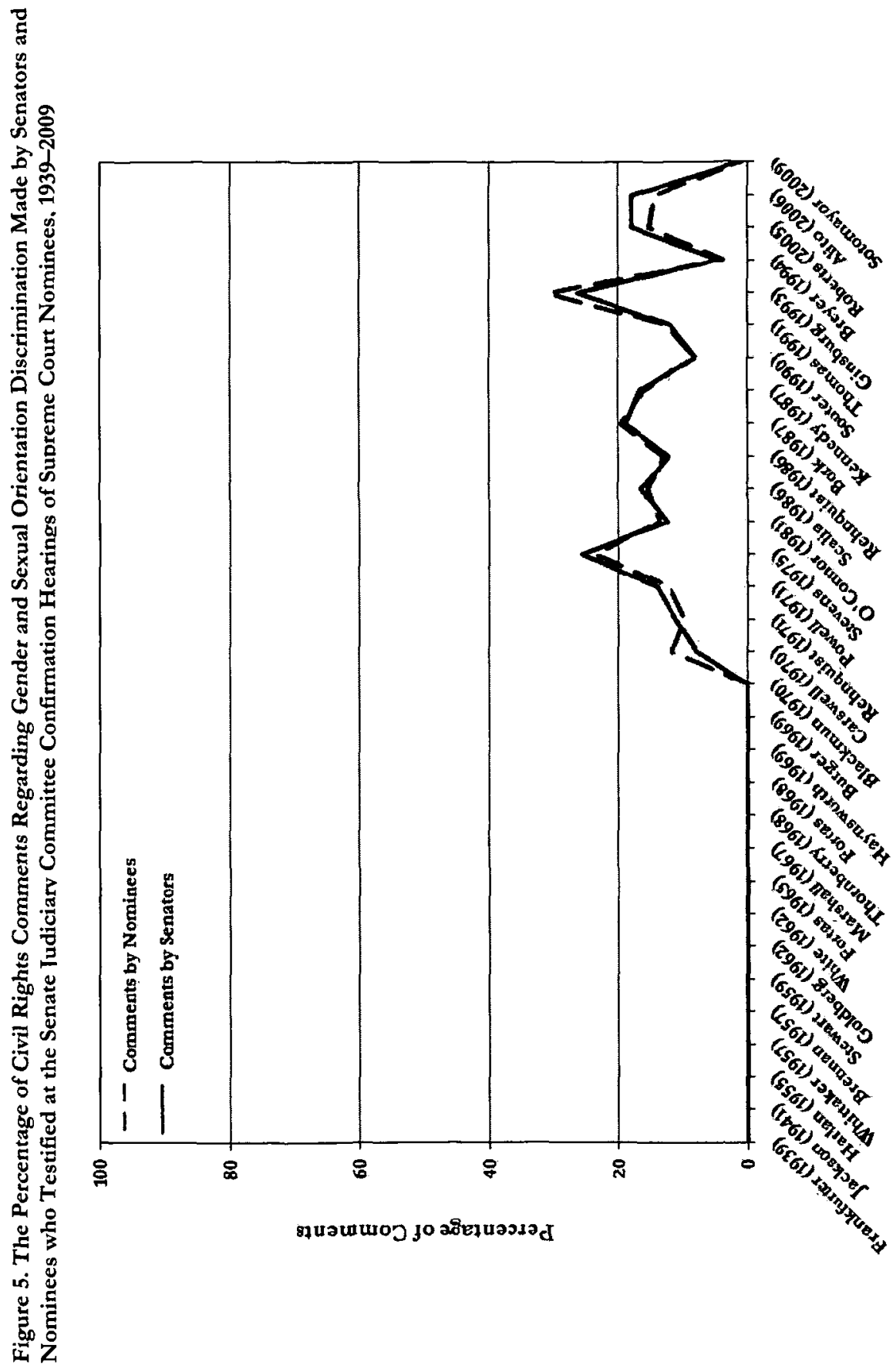

(2004). 
organized in remembrance of Stonewall, followed in 1970, and Ann Arbor, Michigan passed the first gay-rights ordinance in $1972 .{ }^{45}$ As with racial conflicts, it would be surprising if societal changes as revolutionary as these were not reflected in the confirmation hearings.

\section{b. Speech and religious freedoms}

As noted in Table 3, speech and religious freedom is the second most frequently occurring subissue within the civil rights area, constituting $16.5 \%$ of all observations. This subissue includes discussions of, among other things, flag burning, school prayer, obscenity, free exercise of religion, and campaign finance regulation.

Unlike the dialogue concerning race and gender/sexual orientation discrimination, comments involving speech and religious freedom have been relatively evenly dispersed over time, particularly since the late 1960s, as reported in Figure 6 . While not every hearing involved substantial discussions of these issues, there was no time period in the last forty years in which this subissue did not play a relatively important role. Rather, its prevalence has remained quite stable over time, constituting about $10 \%$ to $20 \%$ of civil rights comments for most nominees.

Comments in this subissue, as shown above, were most prominent in the Goldberg, Burger, and, to a lesser extent, Breyer hearings. Most of the Goldberg hearing comments within this subissue occurred within an exchange between Goldberg and Senator Ervin in which Ervin (continuing his post-Brown assault on the Court) asked Goldberg questions such as whether he agreed that "every American citizen has a right to think and to speak his own honest thoughts concerning all things under the sun including the decisions of Supreme Court majorities?" ${ }^{46}$ Goldberg agreed. ${ }^{47}$

The comments made at Justice Burger's hearing were more representative of the direction this subissue would take in future hearings. Burger, confirmed in 1969, was asked very few questions overall (see Figure 1), but the ones he was asked within this subissue

45. See, e.g., id. at 253 (describing the first gay pride parade after the Stonewall riots); James W. Meeker, John Dombrink \& Gilbert Geis, State Law and Local Ordinances in California Barring Discrimination on the Basis of Sexual Orientation, $10 \mathrm{U}$. DAYTON L. REV 745, 756 (1985) (examining the development of local ordinances banning discrimination based on sexual orientation, beginning with the 1972 Ann Arbor ordinance).

46. Nomination of Arthur J. Goldberg, of Illinois, to be Associate Justice of the Supreme Court of the United States Before the S. Comm. on the Judiciary, 87th Cong. 23 (1962).

47. Id. at 23-24. 


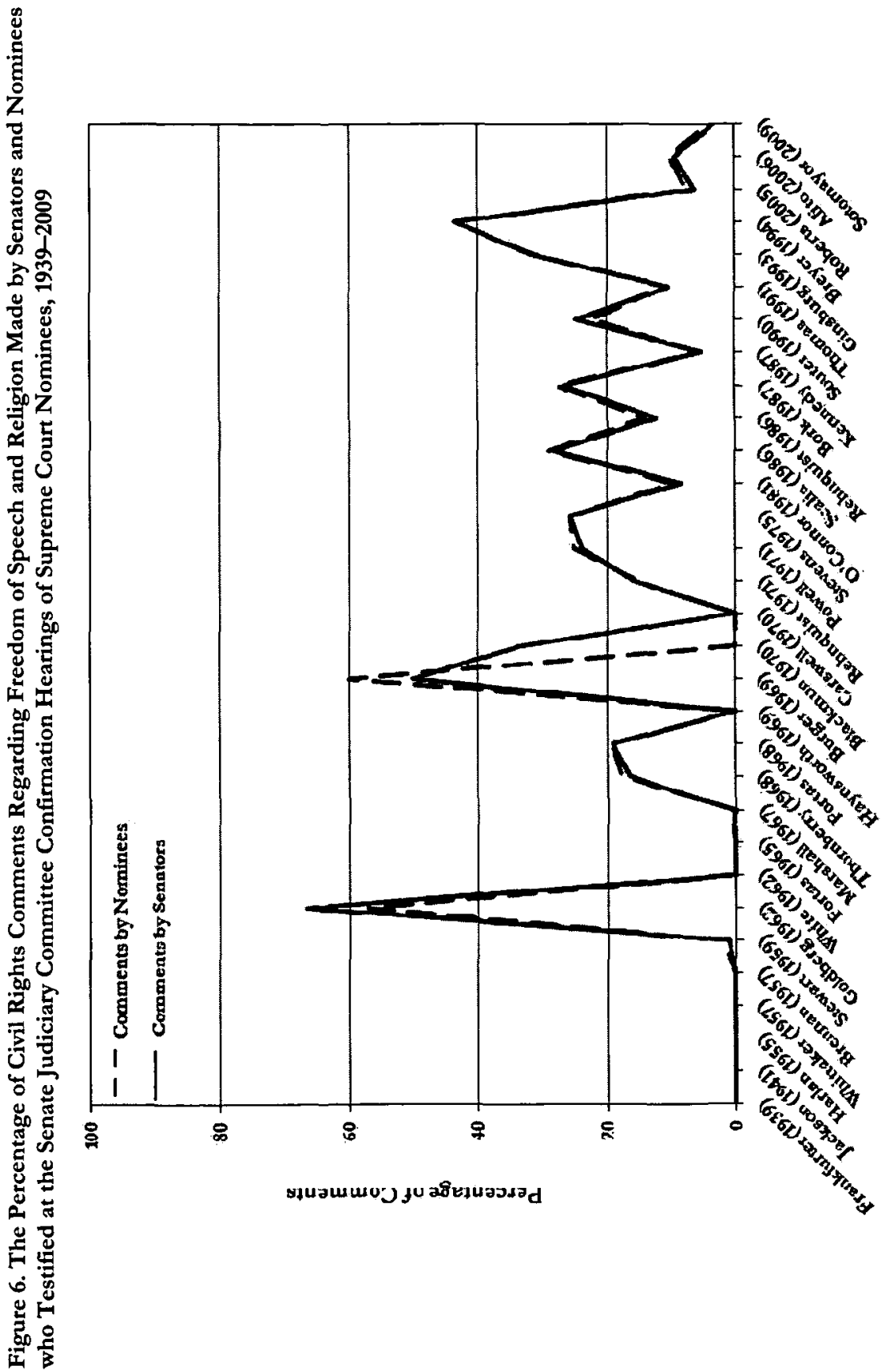


area focused on a school prayer case in which the Court had just denied certiorari. ${ }^{48}$ Despite prodding from the senators, Burger refused to speculate on why the Court declined to hear the case. ${ }^{49}$ Breyer, the most recent nominee for whom this subissue constituted an unusually high percentage of civil rights comments, was likewise asked several questions about school prayer and the religion clauses, as well as numerous speech-related questions. Breyer was somewhat more forthcoming than Burger had been, expressing general agreement with the Court's Establishment Clause jurisprudence as set forth in Lemon $v$. Kurtzman, ${ }^{50}$ but refusing to give an opinion about Free Exercise cases such as Sherbert v. Verner ${ }^{51}$ and Employment Division v. Smith. ${ }^{52}$

\section{c. The right to privacy}

Discussions of privacy unrelated to abortion follow comments involving racial discrimination and First Amendment freedoms, constituting the third most commonly raised subissue in the civil rights issue area; abortion-related privacy placed fifth, after gender and sexual orientation discrimination. Non-abortion privacy discussions constitute $14.7 \%$ of the civil rights comments, while abortion rights comments comprise $12.2 \%$ of that issue area.

The temporal variation involving non-abortion-related and abortion-related privacy comments appears in Figures 7 and 8. Figure 7 reports the percentage of civil rights commentary involving privacy unrelated to abortion, while Figure 8 illustrates the percentage of civil rights commentary that touched on abortion rights. Note that the delineation of abortion and non-abortion privacy comments is important here. Because of the nominees' (and perhaps the senators') reluctance to address abortion-related questions directly, abortion as an issue is frequently addressed through proxy debates, usually involving contraception or Griswold $v$. Connecticut, ${ }^{59}$ the 1965 decision that established the right of married couples to use

48. See Nomination of Warren E. Burger, of Virginia, to be Chief Justice of the United States Before the S. Comm. on the Judiciary, 91st Cong. 18-19 (1969) (question about Stein v. Oshinksy).

49. See id. at 19 (insisting that it would not be appropriate to analyze the Court's reasoning for denying certiorari).

50. 411 U.S. 192 (1973).

51. 374 U.S. 398 (1963).

52. 494 U.S. 872 (1990). For Breyer's discussion of these cases at his hearing, see The Nomination of Stephen G. Breyer to be an Associate Justice of the Supreme Court of the United States Before the S. Comm. on the Judiciary, 103d Cong. 153, 223-24 (1995).

53. 381 U.S. 479 (1965). 


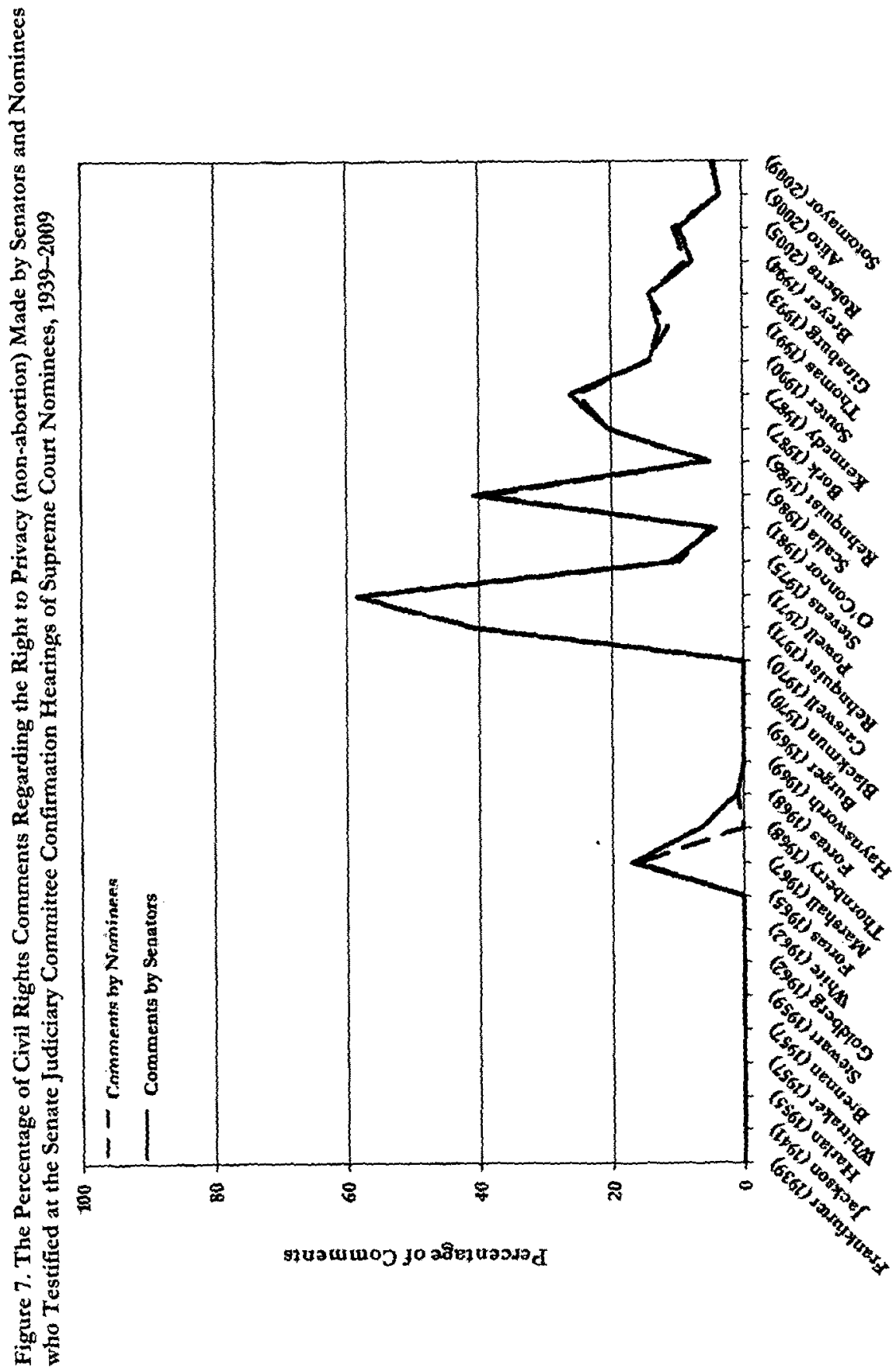




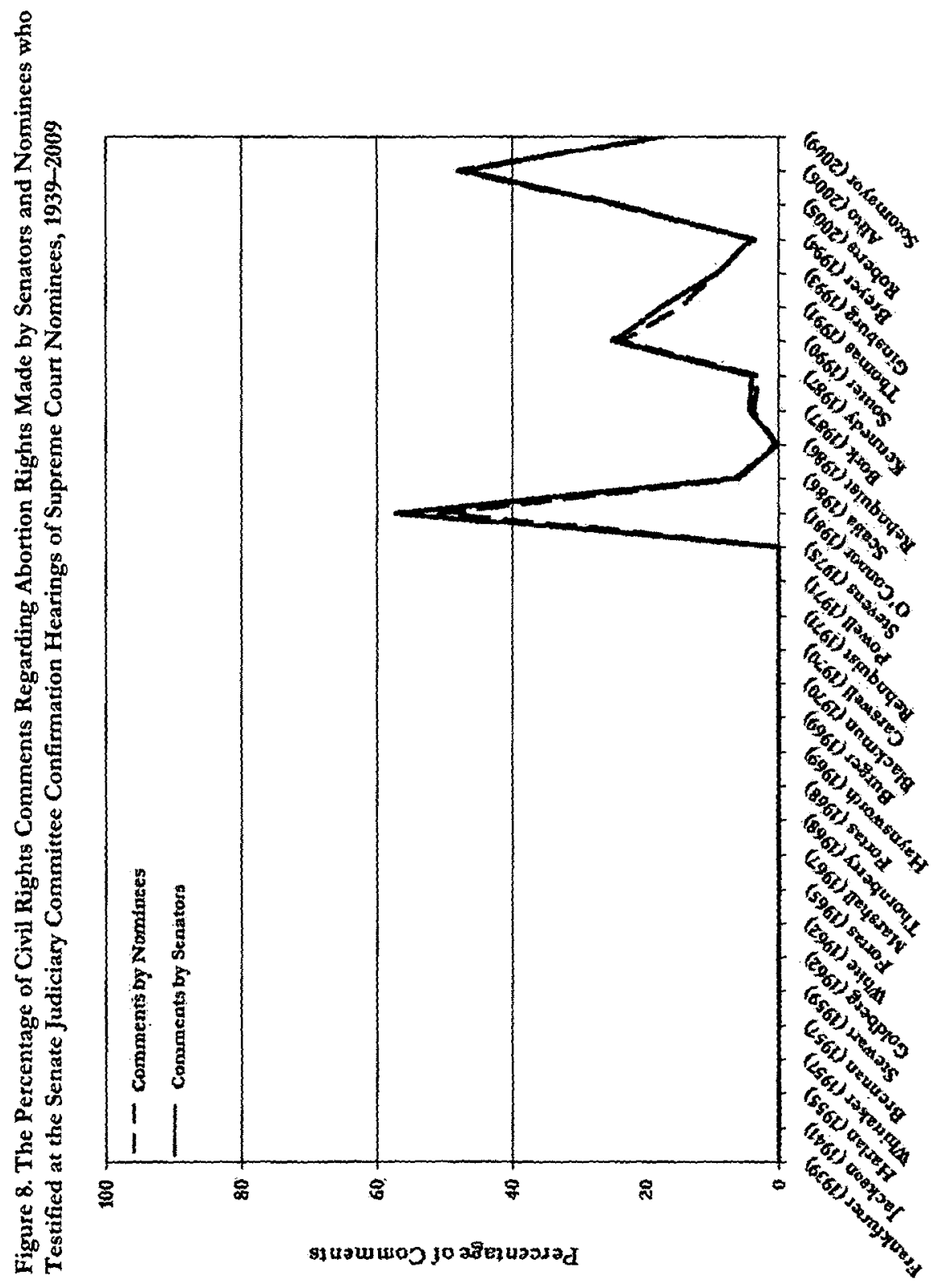


contraception. ${ }^{54}$ To ensure that abortion-related comments were not thereby undercounted in the data, we coded comments involving contraception and Griswold as involving abortion rights. Nonabortion privacy, consequently, consists primarily of comments involving personal or informational privacy, such as police wiretapping, employee drug testing, and privacy of medical records.

This distinction between the two types of privacy comments explains the prevalence of privacy as a subissue at Justice Rehnquist's first confirmation hearing in 1971-two years before Roe was decided-as reported in Figure 7. Also of note is that abortion and non-abortion privacy comments constitute a relatively small percentage of the civil rights comments at the Bork hearing: the distribution of civil rights comments at that hearing was fairly even (as among the category's subissues). Abortion and privacy concerns, in other words, did not dominate that hearing. Issues of race discrimination, gender discrimination, speech and religious freedoms, and non-abortion privacy all played roughly equivalent roles.

That comments on abortion rights constitute a relatively small percentage $(12.2 \%)$ of the civil rights observations in the dataset may be less surprising than it initially appears. Our dataset goes back to 1939 , and abortion only became a controversial constitutional issue after 1973, the year Roe $v$. Wade was decided. What is more surprising than the relative scarcity of abortion comments overall, therefore, may be the fact that such comments have not played a larger role even in the post-Roe era. As shown in Figure 8, abortion rights comments have constituted more than $20 \%$ of the civil rights observations in only four of the thirteen post-Roe hearings: those of O'Conner, Souter, Roberts and Alito. Moreover, even though Roe was decided in 1973, abortion did not become an issue in the hearings until the 1981 O'Connor hearing. Post-Roe dialogue concerning abortion rights constituted $15.6 \%$ of all civil rights discussions, comprising only $5 \%$ of all post-Roe comments in the dataset. Clearly, abortion as a hearing issue took some time to gain traction and failed to dominate the hearings even after it did.

\section{Judicial philosophy}

Judicial philosophy is the third most frequently occurring issue following chatter and civil rights. Comments about judicial philosophy, which include such things as discussions of constitutional 
interpretation, stare decisis and judicial activism, constitute $12.4 \%$ of the comments in the dataset.

Figure 9 reports the percentage of comments involving judicial philosophy for each nominee in the data. Our findings regarding judicial philosophy are particularly noteworthy, in that many commentators, senators, and legal scholars argue that this should be the primary area of senatorial questioning. ${ }^{55}$ Clearly, neither the senators nor the nominees have conformed to such a practice: the substantive area of civil rights comprises more than twice as many comments in our dataset than do comments about judicial philosophy. ${ }^{56}$ Moreover, this focus on issues less esoteric than judicial philosophy has been remarkably consistent over time.

With the exception of the White and Goldberg hearings, the percentage of comments involving judicial philosophy at the hearings has rarely exceeded $20 \%$ and has consistently been in a range of approximately $10 \%$ to $20 \%$ of hearing comments. This is consistent with Professors Guliuzza, Reagan, and Barrett's finding that Judge Bork was not asked more questions about what they labeled "constitutionalism" than were other nominees. ${ }^{57}$ It is, however, as noted above, inconsistent with much of the rhetoric about how hearings "should" be conducted. ${ }^{58}$

Note that the judicial philosophy issue area is limited to observations in which the comment is specifically about constitutional interpretation and/or the nominee's preferred method thereof. When interpretive concerns are raised in the context of discussion about a particular substantive issue, coders were instructed to code by that issue. So, for example, a comment such as that cited above by Senator Ervin, in which he asks Justice Stewart about interpretive methods within a discussion of Brown, would be coded as a civil rights comment. As pointed out in the above discussion, however, this coding rule in practice probably still over-counts judicial philosophy comments because comments in which the substantive issue area is not raised will be coded as comments about judicial philosophy

55. See supra note 8 and accompanying text (suggesting the significant role that judges play in molding one's constitutional values).

56. Republican senators asked more questions about judicial philosophy than did Democratic senators. See infra Part C (examining the role of partisanship in voting behavior among Senators).

57. See Guliuzza et al., supra note 5 (discussing findings on the types of questions asked at the Bork hearing).

58. See supra note 9 and accompanying text (discussing some commentators' suggestion that Bork's nomination hearings changed the confirmation process into the partisan affairs they are today). 


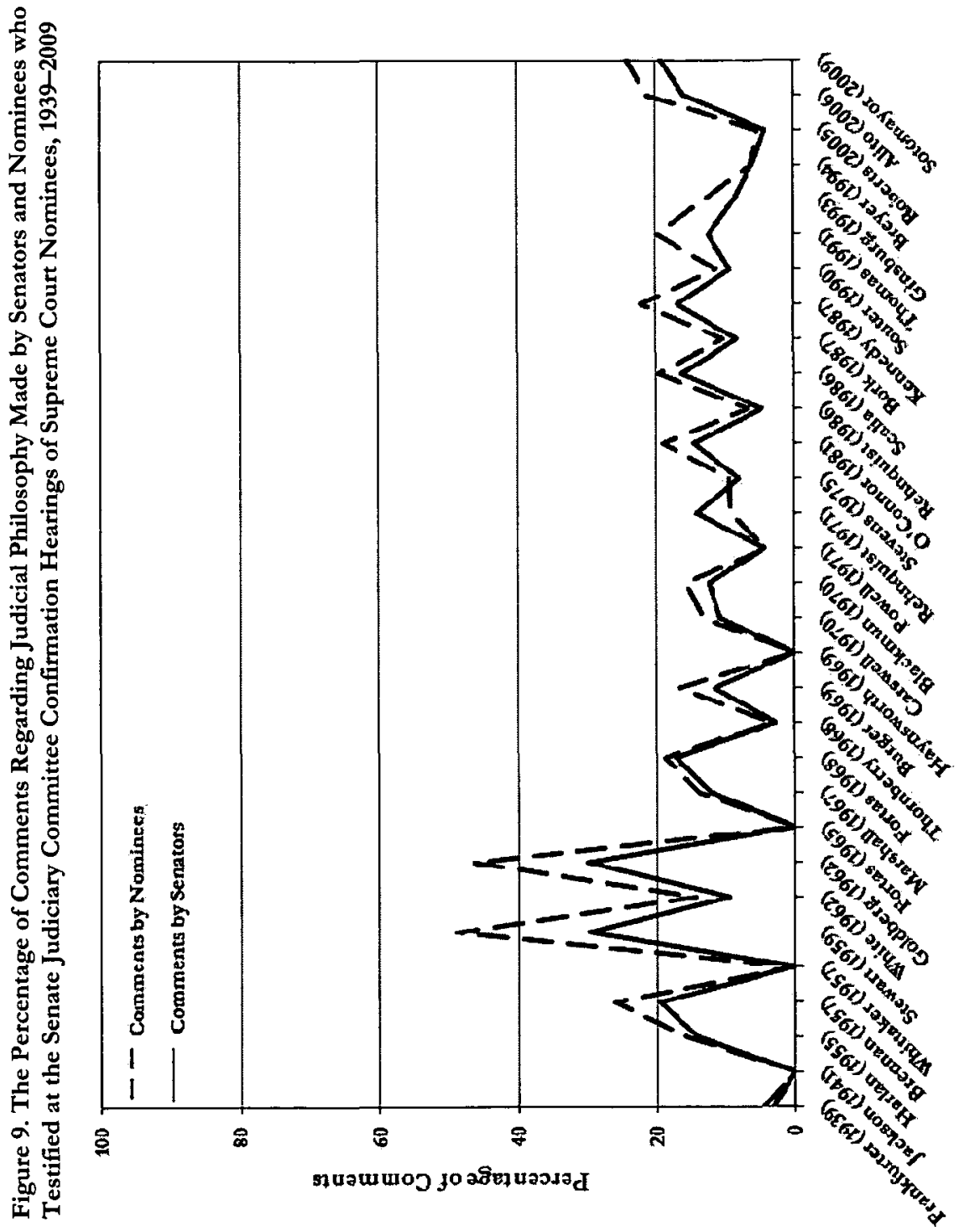


regardless of the senator's motivation in asking the question. Clearly, therefore, the hearings are and have since their inception been more focused on substantive, policy-laden issues of constitutional law rather than on abstracted debates about theories of constitutional interpretation.

\section{Criminal justice}

Criminal justice is the last of the top four issue areas addressed at the hearings. As shown on Table 1, dialogue involving criminal justice issues comprises $8.6 \%$ of the comments in the dataset. This issue area includes topics such as the rights of criminal defendants, organized crime, and juvenile justice. Figure 10 indicates the percentage of comments dedicated to criminal justice issues by nominee. Justice Jackson, who had been Attorney General at the time of his nomination, faced the highest percentage of questions within this issue area, and made the most comments about it. It also was a frequently occurring issue in both of the Fortas hearings (associate and chief justice) and in the Marshall hearing, as well as in Rehnquist's associate justice hearing. Yet, debates involving criminal justice policy have constituted only a small percentage of civil rights dialogue in more contemporary hearings.

\section{Issue Areas and Partisan Affiliation}

Partisanship plays a central role in the American political system. Within the electoral realm, voters overwhelmingly support candidates who share their party identification. ${ }^{59}$ In the legislative arena, partisan affiliation remains an excellent predictor of voting behavior among senators and representatives. ${ }^{60}$ Of course, the judiciary is no different. Indeed, study after study reveals the paramount importance of partisanship in influencing the choices judges make. ${ }^{61}$

59. See generally ANGuS CAMPBELl ET AL., The AMERICAN Voter 136-142 (1960) (reporting statistical findings on the impact of party identification on voting behavior); accord Larry M. Bartels, Partisanship and Voting Behavior, 1952-1996, 44 AM. J. POL. SCI. 35, 35 (2000) (evaluating the relationship between party loyalties and voting behavior).

60. See, e.g., Gregory L. Hager \& Jeffery C. Talbert, Look for the Party Label: Party Influences on Voting in the U.S. House, 25 LEGIS. STUD. Q. 75, 94 (2000) (analyzing the correlation between the behavior of members of Congress and their party affiliation); Samuel C. Patterson \& Gregory A. Caldeira, Party Voting in the United States Congress, 18 BRrT. J. POL. SCI. 111, 128-29 (1988) (concluding that congressional representatives generally vote along party lines but finding differences between the House and the Senate in the propensity for voting along party lines).

61. See Daniel R. Pinello, Linking Party to Judicial Ideology in American Courts: A Meta-Analysis, 20 JUST. SYS. J. 219, 243 (1999) (reaching the conclusion that party affiliation influences the decisions of judges in American courts); CASS R. SUNSTEIN ET al., ARe Judges Political? AN EMPIRICAL ANALYSIS OF THE FEDERAL JUdiCiary 17-22 


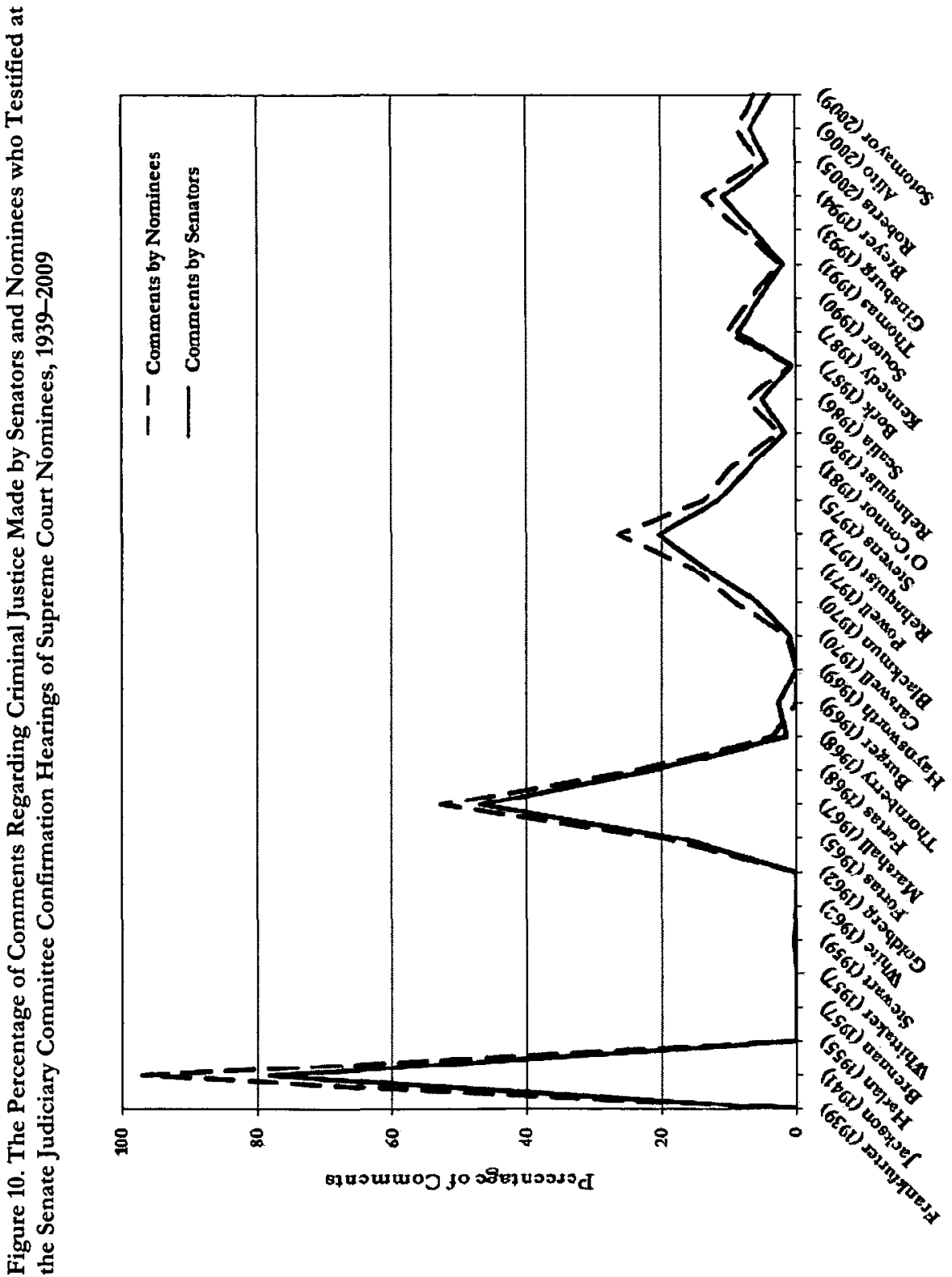

(2006) (conducting research on the occurrence of ideological voting in over six thousand published three-judge panel decisions and finding strong evidence of partisan voting among judges). 
Despite the voluminous body of scholarship devoted to examining the effect of partisanship throughout the American political and legal arenas, we know very little about how partisanship affects the questions senators ask at confirmation hearings of Supreme Court justices. We rectify this state of affairs by exploring below the issues that Democratic and Republican senators and nominees address, in addition to examining whether Democratic senators ask different questions of Republican nominees (and vice versa). Taken as a whole, we find that there are substantial differences involving the types of questions asked and answered by Democrats and Republicans.

\section{The effect of partisan affiliation}

We begin by assessing the issues addressed by Democratic and Republican senators and nominees, which appear in Tables 4 and 5. The first two columns in these tables report the percentage of comments representing each issue area. The third columns indicate the p-values corresponding to two-tailed, unpaired difference of means tests. This allows us to establish whether there are statistically significant differences between the issue areas Democratic and Republican senators and nominees address. For ease of interpretation, $p$-values appearing in bold denote that the difference of means is statistically significant at $p<0.05$ using two-tailed tests.

Table 4 reports the issues addressed by Democratic and Republican senators. Several notable differences emerge. First, Democratic senators more often engaged nominees in chatter than did Republican senators. In part, this reflects the fact that $71 \%$ of the comments made by senators occurred during periods of Democratic control of the Senate Judiciary Committee, in which a Democratic senator served as chair. Second, Republican senators more often asked nominees about judicial philosophy and statutory interpretation than did Democratic senators. With regard to judicial philosophy, $14 \%$ of the questions from Republican senators involved the nominees' preferred method of constitutional interpretation, compared to only $9.4 \%$ of questions from Democrats. Regarding statutory interpretation, $1.4 \%$ of the questions from Republican senators queried nominees as to issues involving legislative intent and history, while Democrats only addressed this issue in $0.4 \%$ of questions. Third, Democratic senators focused more attention on criminal justice than did their Republican counterparts. While $8.9 \%$ of questions from Democrats touched on criminal justice issues, only $5.8 \%$ of questions from Republicans did so. 
Table 4. The Issues Addressed by Democratic and Republican Senators at the Senate Judiciary Committee Confirmation Hearings of Supreme Court Nominees, 1939-2009

\begin{tabular}{llll}
\hline Issue & $\begin{array}{c}\text { Democratic } \\
\text { Senators }\end{array}$ & $\begin{array}{c}\text { Republican } \\
\text { Senators }\end{array}$ & $\begin{array}{c}\text { P-value } \\
\text { for t-test }\end{array}$ \\
\hline Hearing Administration/Chatter & $43.3 \%(4,258)$ & $39.4 \%(2,400)$ & $<0.001$ \\
Civil Rights & $26.5 \%(2,601)$ & $27.3 \%(1,665)$ & 0.223 \\
Judicial Philosophy & $9.4 \%(923)$ & $\mathbf{1 4 . 0 \% ( 8 5 4 )}$ & $<\mathbf{0 . 0 0 1}$ \\
Criminal Justice & $\mathbf{8 . 9 \% ( 8 7 8 )}$ & $5.8 \%(353)$ & $<\mathbf{0 . 0 0 1}$ \\
Govemment Operations & $3.1 \%(304)$ & $3.6 \%(217)$ & 0.105 \\
Court Administration & $3.1 \%(304)$ & $2.7 \%(162)$ & 0.115 \\
Federalism & $1.0 \%(98)$ & $1.3 \%(79)$ & 0.079 \\
Statutory Interpretation & $0.4 \%(39)$ & $1.4 \%(88)$ & $<0.001$ \\
Banking and Finance & $0.9 \%(89)$ & $0.6 \%(34)$ & $\mathbf{0 . 0 1 5}$ \\
Labor and Employment & $0.8 \%(74)$ & $0.4 \%(24)$ & $\mathbf{0 . 0 0 5}$ \\
Standing/Access to Courts & $0.6 \%(50)$ & $0.6 \%(35)$ & 0.968 \\
Best/Favorite Justices & $0.3 \%(33)$ & $0.4 \%(25)$ & 0.447 \\
National Defense & $0.2 \%(24)$ & $0.6 \%(35)$ & $\mathbf{0 . 0 0 1}$ \\
Othet Issues & $1.6 \%(153)$ & $2.0 \%(123)$ & $\mathbf{0 . 0 3 0}$ \\
Totals & $100.1 \%(9,834)$ & $100.1 \%(6,094)$ &
\end{tabular}

The unit of analysis is the change of speaker. The entries in columns one and two represent the percentage of comments regarding each issue area. The percentages do not sum to $100 \%$ due to rounding. The numbers in parentheses indicate the total number of comments pertaining to each issue area. The entries in column three report the p-values corresponding to two-tailed, unpaired difference of means tests. P-value entries appearing in bold indicate that the difference of means is statistically significant at $p<.05$ (two-tailed tests). Issue areas representing less than $0.4 \%$ of the column totals in Table 1 are combined into the "Other Issues" category. The data contain information on Supreme Court nominees, both confirmed and unconfimed, who appeared in front of an open session of the Senate Judiciary Committee since 1939

Table 5. The Issues Addressed by Democratic and Republican Nominees who Testified at the Senate Judiciary Committee Confirmation Hearings of Supreme Court Nominees, 1939-2009

\begin{tabular}{llll}
\hline Issue & $\begin{array}{c}\text { Democratic } \\
\text { Nomines }\end{array}$ & $\begin{array}{c}\text { Republican } \\
\text { Nominees }\end{array}$ & $\begin{array}{c}\text { P-value } \\
\text { for t-test }\end{array}$ \\
\hline Hearing Administration/Chatter & $21.8 \%(681)$ & $28.1 \%(2,453)$ & $<0.001$ \\
Civil Rights & $29.3 \%(914)$ & $35.4 \%(3.089)$ & $<0.001$ \\
Judicial Philosophy & $14.5 \%(453)$ & $13.9 \%(1,214)$ & 0.398 \\
Criminal Justice & $20.3 \%(635)$ & $6.0 \%(526)$ & $<0.001$ \\
Govemment Operations & $2.2 \%(68)$ & $4.8 \%(417)$ & $<0.001$ \\
Court Administration & $1.9 \%(59)$ & $4.4 \%(387)$ & $<0.001$ \\
Federalism & $1.0 \%(32)$ & $1.7 \%(145)$ & 0.012 \\
Statutory Interpretation & $1.6 \%(49)$ & $0.9 \%(78)$ & 0.002 \\
Banking and Finance & $1.7 \%(53)$ & $0.8 \%(67)$ & $<0.001$ \\
Labor and Employment & $0.6 \%(19)$ & $0.9 \%(77)$ & 0.144 \\
Standing/Access to Courts & $0.6 \%(18)$ & $0.8 \%(67)$ & 0.279 \\
Best/Favorite Justices & $0.4 \%(12)$ & $0.5 \%(46)$ & 0.328 \\
National Defense & $0.4 \%(12)$ & $0.5 \%(43)$ & 0.446 \\
Other Issues & $3.8 \%(118)$ & $1.5 \%(129)$ & $<0.001$ \\
& & &
\end{tabular}

\footnotetext{
The unit of analysis is the change of speaker. The entries in columns one and two represent the percentage of comments regarding each issue area. The percentages do not sum to $100 \%$ duc to rounding. The numbers in parentheses indicate the total number of comments pertaining to each issue area. The entries in column three report the p-values corresponding to two-tailed, unpaired difference of means tests. P-value entries appearing in bold indicate that the difference of means is statistically significant at $p<.05$ (two-tailed tests). Issue areas representing less than $0.4 \%$ of the column totals in Table 1 are combined into the "Other Issues" category. The data contain information on Supreme Court nominees, both confirmed and unconfimed, who appeared in front of an open session of the Senate Judiciary Committee since 1939
} 
Several additional differences are apparent from our data. For example, Democratic senators focused more attention on banking and finance and labor and employment than did Republicans, while Republicans asked three times as many questions regarding national defense than did Democrats. For all of the other issues reported in Table 4 , the differences between the issues raised by Democratic and Republican senators fail to attain statistical significance.

Table 5 provides information on the issues addressed by Democratic and Republican nominees. Interestingly, while Democratic senators more often engaged nominees in chatter, as compared to Republican senators, Republican nominees partook in $6 \%$ more chatter than Democratic nominees. Also note that Republican nominees spoke more to civil rights issues than Democratic nominees. Specifically, Republican nominees addressed civil rights issues in $35.4 \%$ of their comments, while Democratic nominees touched on civil rights issues only $29.3 \%$ of the time. This may evidence an effort on the part of Republican nominees to respond to skepticism from Democratic senators regarding their commitment to preserving constitutional protection for various civil rights.

The biggest difference in terms of the issue areas addressed by Democratic and Republican nominees, however, involves criminal justice. More than one-fifth of the comments made by Democratic nominees involved criminal justice, compared to only $6 \%$ of the comments made by Republican nominees. Notably, while Democratic nominees spoke to statutory interpretation more often than Republican nominees, there is no statistically significant difference in terms of comments regarding the nominees' preferred methods of judicial interpretation. Thus, while it is evident that Republican senators asked more questions about judicial philosophy than did Democratic senators, the nominees themselves addressed this issue in more or less equal terms.

There are additional differences that emerge from Table 5. In particular, Republican nominees commented on government operations, court administration, and federalism roughly twice as often as Democratic nominees, while Democratic nominees more frequently addressed issues involving banking and finance.

\section{The interaction of the partisanship of senators and nominees}

Thus far, we have provided information regarding comments addressed by Democratic and Republican senators and nominees. We have not, however, presented a description of the variation in the 
issues addressed in confirmation hearings by the party affiliation of the senator and that of the nominee. This is vital information in that it affords us an opportunity to determine if, for example, Democratic and Republican senators ask different questions of Democratic nominees. Inasmuch as party affiliation is a vital component of Senate confirmation hearings, such an analysis allows us to delve deeper into the partisanship that permeates the Senate confirmation process.

Table 6 reports the issues addressed by Democratic and Republican senators by nominee partisanship. Columns one, two, four, and five represent the percentage of comments in each issue area, while columns three and six report the p-values corresponding to twotailed, unpaired difference of means tests. As before, to aid in interpretation, we have bolded p-values denoting that the difference of means between Democratic and Republican senators is statistically significant at $p<0.05$ using two-tailed tests.

Beginning with hearing administration and chatter, Table 6 reveals that Democratic senators engaged in substantially more nonsubstantive questioning of Democratic nominees than did Republican senators. Specifically, $42.6 \%$ of the comments made by Democratic senators to Democratic nominees involved hearing administration and chatter, while only $28.5 \%$ of comments made by Republican senators to Democratic nominees involved nonsubstantive discussions. However, there is no statistically significant difference between the amount of commentary regarding hearing administration and chatter with regard to Democratic and Republican senators facing Republican nominees.

The results regarding partisanship and civil rights commentary are particularly interesting. On the one hand, Republican senators engaged Democratic nominees in far more questioning pertaining to civil rights $(30.6 \%)$ than did Democratic senators $(18.5 \%)$. On the other hand, Democratic senators partook in slightly more civil rights interrogation with regard to Republican nominees $(29.3 \%)$ than did Republican senators $(26.2 \%)$. This suggests that members of the opposing party of the nominee are especially likely to press that nominee on civil rights issues, no doubt in an attempt to discern how closely the nominee meshes with his or her political party's stance on the pressing civil rights issues of the day.

Table 6 also illustrates that Republican senators dominated conversations regarding judicial philosophy, statutory interpretation, and national defense, regardless of the nominee's partisanship. Indeed, $14.5 \%$ of the questions from Republican senators to 
Table 6. The Issues Addressed by Democratic and Republican Senators, by Nominee Partisanship, at the Senate Judiciary Cormittee Confirmation Hearings of Supreme Court Nominees, 1939-2009

\begin{tabular}{|c|c|c|c|}
\hline \multirow[b]{2}{*}{ Issue } & \multicolumn{3}{|c|}{ Democratic Nominees } \\
\hline & $\begin{array}{l}\text { Democratic } \\
\text { Senators }\end{array}$ & $\begin{array}{c}\text { Republican } \\
\text { Senators }\end{array}$ & $\begin{array}{l}\text { P-value } \\
\text { for } t \text {-test }\end{array}$ \\
\hline Hearing Administration/Chatter & $42.6 \%(1,114)$ & $28.5 \%(442)$ & $<0.001$ \\
\hline Civil Rights & $18.5 \%(483)$ & $30.6 \%(475)$ & $<0.001$ \\
\hline Judicial Philosophy & $9.8 \%(250)$ & $14.5 \%(225)$ & $<0.001$ \\
\hline Criminal Justice & $19.4 \%(508)$ & $12.2 \%(190)$ & $<0.001$ \\
\hline Govemment Operations & $1.5 \%(40)$ & $26 \%(40)$ & 0.017 \\
\hline Court Administration & $2.1 \%(55)$ & $0.3 \%(4)$ & $<0.001$ \\
\hline Federalism & $0.6 \%(15)$ & $1.2 \%(18)$ & 0.039 \\
\hline Statutory Interpre tarion & $0.8 \%(21)$ & $20 \%(31)$ & $<0.001$ \\
\hline Banking and Finance & $1.6 \%(43)$ & $0.8 \%(12)$ & 0.017 \\
\hline Labor and Employment & $0.4 \%(10)$ & $0.7 \%(11)$ & 0.150 \\
\hline Standing/Access to Courts & $0.3 \%(8)$ & $0.9 \%(14)$ & 0.010 \\
\hline Best/Favorite Justices & $0.3 \%(8)$ & $0.1 \%(1)$ & 0.105 \\
\hline National Defense & $0.2 \%(4)$ & $0.5 \%(7)$ & 0.070 \\
\hline Other Issues & $1.9 \%(50)$ & $5.3 \%(82)$ & $<0.001$ \\
\hline \multirow[t]{3}{*}{ Totals } & $100 \%(2,615)$ & $1002 \%(1,552)$ & \\
\hline & \multicolumn{3}{|c|}{ Republican Nominees } \\
\hline & $\begin{array}{l}\text { Democratic } \\
\text { Senators }\end{array}$ & $\begin{array}{l}\text { Republican } \\
\text { Senators }\end{array}$ & $\begin{array}{l}\text { P-value } \\
\text { for t-test }\end{array}$ \\
\hline Hearing Administration/Chatter & $43.5 \%(3,144)$ & $43.1 \%(1,958)$ & 0.637 \\
\hline Civil Rights & $29.3 \%(2,118)$ & $262 \%(1,190)$ & $<0.001$ \\
\hline Judicial Philosophy & $9.2 \%(667)$ & $13.9 \%(629)$ & $<0.001$ \\
\hline Criminal Justice & $5.1 \%(370)$ & $3.6 \%(163)$ & $<0.001$ \\
\hline Govemment Operations & $3.7 \%(264)$ & $3.9 \%(177)$ & 0.505 \\
\hline Court Administration & $3.5 \%(249)$ & $3.5 \%(158)$ & 0.932 \\
\hline Federalism & $1.2 \%(83)$ & $1.3 \%(61)$ & 0.354 \\
\hline Statutory Interpretation & $0.3 \%(18)$ & $1.3 \%(57)$ & $<0.001$ \\
\hline Banking and Finance & $0.6 \%(46)$ & $0.5 \%(22)$ & 0.287 \\
\hline Labor and Employment & $0.9 \%(64)$ & $0.3 \%(13)$ & $<0.001$ \\
\hline Standing/Access to Courts & $0.7 \%(48)$ & $0.5 \%(21)$ & 0.161 \\
\hline Best/Favorite Justices & $0.4 \%(25)$ & $0.5 \%(24)$ & 0.136 \\
\hline National Defense & $0.3 \%(20)$ & $0.6 \%(28)$ & 0.005 \\
\hline Other Issues & $1.4 \%(103)$ & $0.9 \%(41)$ & 0.012 \\
\hline Totals & $100.1 \%(7,219)$ & $100.1 \%(4,542)$ & \\
\hline
\end{tabular}

The unit of analysis is the change of speaker. The entries in columns one, two, four, and five represent the percentage of comments regarding each issue area. The percentages do not necessarily sum to $100 \%$ due to rounding. The numbers in parentheses indicate the total number of comments pertaining to each issue area. The entries in column three and six report the p-values correponding to two-tailed, unpaired difference of means tests. P-value entries appearing in bold indicate that the difference of means is statistically significant at $p<.05$ (two-tailed tests). Issue areas representing less than $0.4 \%$ of the column totals in Table 1 are combined into the "Other Issues" category. The data contain information on Supreme Court nominees, both confirmed and unconfirmed, who appeared in front of an open session of the Senate Judiciary Committee since 1939.

Democratic nominees involved judicial philosophy, compared to $9.8 \%$ of questions from Democratic senators. Similarly, $13.9 \%$ of questions from Republican senators to Republican nominees implicated judicial philosophy, while only $9.2 \%$ of questions from Democratic senators to Republican nominees touched on this issue area. Republican senators also queried Democratic nominees about statutory interpretation more than twice as often as Democratic senators, and they interrogated Republican nominees on this issue almost four times as often as Democratic nominees. Further, Republicans addressed issues of national security about twice as often 
as their Democratic counterparts, regardless of nominee partisanship (although the p-value corresponding to Democratic nominees is only significant at 0.070 ).

These figures reveal that, in a real way, the Republican Party has taken ownership of inquisitions regarding judicial philosophy, statutory interpretation, and national defense at the confirmation hearings-irrespective of whether the nominee was appointed by a Democratic or Republican president. ${ }^{62}$ Even among Republican senators, however, such queries constitute only $16 \%$ of all of the comments those senators made at the hearings.

While it is apparent that Republican senators focused substantial attention on questions involving judicial philosophy, statutory interpretation, and national security, Table 6 illustrates the fact that Democratic senators more often canvassed nominees of both political stripes regarding criminal justice issues than did Republicans. In particular, $19.4 \%$ of questions from Democratic senators to Democratic nominees involved criminal justice, compared to $12.2 \%$ of questions from Republican senators. With regard to Republican nominees, $5.1 \%$ of questions from Democrats involved criminal rights, while only $3.6 \%$ of queries from Republican senators touched on this issue. Thus, notwithstanding the fact that the appointment of "law and order" judges is most commonly associated with the Republican Party, and Richard Nixon in particular, ${ }^{63}$ Democratic senators, perhaps in an effort to secure Warren Court precedents involving the rights of the criminally accused, focused on this issue much more often than did their Republican counterparts.

The remaining issue areas reported in Table 6 exhibit less consistent variation. For example, while Republican senators engaged Democratic nominees in more discussions of government operations, federalism, and access to courts than did Democratic senators, these differences do not hold for Republican nominees. In addition, Table 5 reveals that Democratic senators asked more

62. See generally Noah Kaplan et al., Dialogue in American Political Campaigns? An Examination of Issue Convergence in Candidate Television Advertising, 50 AM. J. POL. SCI. 724, 731 (2006) (applying the issue ownership theory in the context of candidate television advertising); John R. Petrocik et al., Issue Ownership and Presidential Campaigning, 1952-2000, 118 POL. SCI. Q. 599, 599-600 (2003) (discussing issue ownership theory in presidential elections from 1952 to 2000).

63. E.g., JefFrey A. Segal \& Harold J. Spaeth, The Supreme Court and the ATTITUDINAL MODEL REVISITED 181 (2002) (stating that Nixon promised in his 1968 campaign to "appoint justices who would support the 'peace forces' of society instead of those who favored the rights of accused criminals"); C.K. Rowland \& Bridget Jeffery Todd, Where You Stand Depends on Who Sits: Platform Promises and Judicial Gatekeeping in the Federal District Courts, 53 J. PoL. 175, 176 (1991) (acknowledging Nixon's explicit promise to appoint judges committed to "law and order"). 
questions of Democratic nominees regarding banking and finance, and more questions of Republican nominees involving labor and employment, than Republican senators, but these differences do not apply to Republican nominees for banking and finance and Democratic nominees with respect to labor and employment.

\section{Nominee Race and Gender}

Issues of gender and race have garnered substantial attention with regard to the nomination and confirmation of federal judges. ${ }^{64}$ This is perhaps no more evident than in Justice O'Connor's comments regarding President George W. Bush's first choice to succeed her on the Court. In opining about the nomination of Judge John Roberts to fill her seat, O'Connor noted, "He's good in every way, except he's not a woman." ${ }^{65}$ Similar notions exist with regard to the importance of diversifying the Court in terms of its racial composition. For example, some have attributed President George H. W. Bush's choice of Judge Clarence Thomas to the fact Bush needed to fill the "black seat" vacated by Thurgood Marshall. ${ }^{66}$

Despite the fact that issues of race and gender have become staples of nomination and confirmation rhetoric, we know surprisingly little about whether racial minorities and women are treated differently in Senate confirmation hearings. We rectify this lacuna by investigating the types of questions senators ask minority nominees for the

64. See, e.g., Paul M. Collins, Jr. et al., Gender, Critical Mass, and Judicial Decision Making, 32 L. \& PoL'Y 260, 265-66, (2010) (noting the substantial strides women have made in becoming federal judges over the past thirty years); Lisa A. Solowiej et al., Partisan Politics: The Impact of Party in the Confirmation of Minority and Female Federal Court Nominees, 11 PARTY POL. 557, 569-70 (2005) (determining that women judicial nominees are most advantaged under unified Republican control of Congress and the Presidency and most disadvantaged under divided control with a Democratic President); Thomas G. Walker \& Deborah J. Barrow, The Diversification of the Federal Bench: Policy and Process Ramifications, 47 J. PoL. 596, 613-14 (1985) (reporting findings that minority and female judges do not advocate for race or gender motivated interests); Jennifer L. Peresie, Note, Female Judges Matter: Gender and Collegial Decisionmaking in the Federal Appellate Courts, 114 YALE L.J. 1759, 1761 (2005) (analyzing over five hundred federal appellate cases decided from 1999-2001 to find that plaintiffs in sexual harassment or sex discrimination cases under Title VII of the Civil Rights Act of 1964 were twice as likely to prevail when the judge was female).

65. Dan Balz \& Darryl Fears, Some Disappointed Nominee Won't Add Diversity to Court, WASH. POST, July 21, 2005, at A15.

66. See, e.g., Henry J. Abraham, Justices, Presidents, and Senators 51, 231 (5th ed. 2008) (asserting that Lyndon Johnson's nomination of Thurgood Marshall to the Supreme Court established "a black seat" on the bench); Thomas R. Marshall, The Supreme Court and the Grass Roots: Whom Does the Court Represent Best?, 76 JUDICATURE 22, 23 (1992) (stating that the existence of a "black seat" and a "woman's seat" are the "clearest concessions to group representation"); Barbara A. Perry \& Henry J. Abraham, A 'Representative' Supreme Court? The Thomas, Ginsburg, and Breyer Appointments, 81 JUDICATURE 158, 159 (1998) (arguing that Clarence Thomas' nomination was "unquestionably" motivated by race). 
purpose of determining if the issues facing women and racial minority nominees differ from those posed to white male nominees.

Table 7 reports the issues addressed by senators, separated by nominee race and gender. Columns one and two represent the percentage of comments in each issue for minority nominees (column one) and white nominees (column two) ${ }^{67}$ Columns four and five indicate the percentage of comments in each issue area for female nominees (column four) and male nominees (column five). Column three reports the p-values corresponding to two-tailed, unpaired difference of means tests that compare minority nominees to white nominees. Column six provides this same information with respect to female and male nominees. To assist in interpretation of these statistics, we have bolded p-values denoting that the difference of means between minority and white nominees, and female and male nominees, is statistically significant at $p<0.05$ using two-tailed tests.

Several notable differences emerge from Table 7. First, it is evident that senators engaged in less chatter for both minority and female nominees. Hearing administration and chatter represents $36.2 \%$ of the comments made by senators to minority nominees, compared to $42.9 \%$ for white nominees. Similarly, chatter represents $39.3 \%$ of senatorial commentary for female nominees, compared to $42.2 \%$ for male nominees. This distinction is particularly striking given that a nominee's personal background-frequently discussed in celebratory terms in the hearings of minority and female nominees-are included within the chatter issue area. This indicates that senators have engaged minority and female nominees in more substantive questioning than white male nominees.

67. Marshall, Sotomayor, and Thomas represent the minority nominees, while Ginsburg, O'Connor, and Sotomayor represent the female nominees. Note that Professor Ringhand has posited that Frankfurter was perceived to be a minority nominee during his confirmation hearing. Lori A. Ringhand, Aliens on the Bench: Lessons in Identity, Race and Politics from the First "Modern" Supreme Court Confirmation Hearing to Today, 2011 MICH. ST. L. REV. (forthcoming 2011). When we include Frankfurter among the minority nominees, the results do not substantively change. Note also that we examined the distinctions between minority nominees and white nominees using hearings beginning with Marshall. None of our conclusions changed in any meaningful way. However, when we compare female nominees to male nominees using the 1981 to 2009 time period (beginning with O'Connor) three minor differences emerge. First, we find that male nominees are asked statistically significantly more questions regarding civil rights than female nominees. In other words, the p-value pertaining to civil rights becomes significant at $p<0.001$. Second, we find that female nominees are presented with statistically significantly more questions regarding criminal justice than males. Finally, we discover that male nominees are asked statistically significantly more questions regarding statutory interpretation than females. That is, the p-value corresponding to statutory interpretation becomes significant at $\mathrm{p}=0.003$. 
Table 7. The Issues Addressed by Senators, by Nominee Race and Gender, at the Senate Judiciary Committee Confirmation Hearings of Supreme Court Nominees, 1939-2009

\begin{tabular}{|c|c|c|c|}
\hline \multirow[b]{2}{*}{ Issue } & \multicolumn{3}{|c|}{ Nominee Race } \\
\hline & $\begin{array}{l}\text { Minority } \\
\text { Nominees }\end{array}$ & $\begin{array}{c}\text { White } \\
\text { Nominees }\end{array}$ & $\begin{array}{c}\text { P-value } \\
\text { for t-test }\end{array}$ \\
\hline Hearing Administration/Chatter & $36.2 \%(970)$ & $42.9 \%(5,688)$ & $<0.001$ \\
\hline Civil Rights & $27.3 \%(733)$ & $26.7 \%(3,533)$ & 0.475 \\
\hline Judicial Philosophy & $14.2 \%(380)$ & $10.6 \%(1,397)$ & $<0.001$ \\
\hline Criminal Jusrice & $15.2 \%(407)$ & $6.2 \%(824)$ & $<0.001$ \\
\hline Govemment Operations & $1.5 \%(40)$ & $3.6 \%(481)$ & $<0.001$ \\
\hline Court Administration & $1.3 \%(34)$ & $3.3 \%(432)$ & $<0.001$ \\
\hline Federalism & $0.5 \%(14)$ & $1.2 \%(163)$ & 0.001 \\
\hline Statutory Interpretation & $0.4 \%(11)$ & $0.9 \%(116)$ & 0.014 \\
\hline Banking and Finance & $1.5 \%(39)$ & $0.6 \%(84)$ & $<0.001$ \\
\hline Labor and Employment & $0.6 \%(16)$ & $0.6 \%(82)$ & 0.893 \\
\hline Standing/Access to Courts & $0.2 \%(4)$ & $0.7 \%(87)$ & 0.002 \\
\hline Best/Favorite Justices & $0.3 \%(7)$ & $0.4 \%(51)$ & 0.331 \\
\hline National Defense & $0.4 \%(10)$ & $0.4 \%(49)$ & 0.981 \\
\hline Other Issues & $0.6 \%(16)$ & $2.0 \%(260)$ & $<0.001$ \\
\hline \multirow[t]{3}{*}{ Totals } & $\begin{array}{l}100.2 \% \\
(2,681)\end{array}$ & \multicolumn{2}{|l|}{$100.1 \%(13,247)$} \\
\hline & \multicolumn{3}{|c|}{ Nominee Gender } \\
\hline & $\begin{array}{l}\text { Female } \\
\text { Nominees }\end{array}$ & $\begin{array}{c}\text { Male } \\
\text { Nominees }\end{array}$ & $\begin{array}{r}\text { P-value } \\
\text { for } t \text {-test }\end{array}$ \\
\hline Hearing Administration/Chatter & $39.3 \%(809)$ & $42.2 \%(5,849)$ & 0.014 \\
\hline Civil Rights & $25.3 \%(520)$ & $27.0(3,740)$ & 0.096 \\
\hline Judicial Philosophy & $13.9 \%(286)$ & $10.8 \%(1,491)$ & $<0.001$ \\
\hline Criminal Justice & $5.5 \%(113)$ & $8.1 \%(1,118)$ & $<0.001$ \\
\hline Govemment Operations & $2.3 \%(48)$ & $3.4 \%(473)$ & 0.010 \\
\hline Court Administration & $4.1 \%(84)$ & $2.8 \%(382)$ & $<0.001$ \\
\hline Federalism & $1.5 \%(31)$ & $1.1 \%(146)$ & 0.067 \\
\hline Statutory Interpretation & $0.5 \%(10)$ & $0.8 \%(117)$ & 0.089 \\
\hline Banking and Finance & $1.8 \%(36)$ & $0.6 \%(87)$ & $<0.001$ \\
\hline Labor and Employment & $0.6 \%(12)$ & $0.6 \%(86)$ & 0.842 \\
\hline Standing/Access to Courts & $1.0 \%(21)$ & $0.5 \%(70)$ & 0.004 \\
\hline Best/Favorite Justices & $0.3 \%(7)$ & $0.4 \%(51)$ & 0.846 \\
\hline National Defense & $0.3 \%(7)$ & $0.4 \%(52)$ & 0.809 \\
\hline Other Issues & $3.6 \%(74)$ & $1.5 \%(202)$ & $<0.001$ \\
\hline Totals & $100 \%(2,058)$ & $100.2 \%(13,870)$ & \\
\hline
\end{tabular}

The unit of analysis is the change of speaker. The entries in columns one, two, four, and five represent the percentage of comments regarding each issue area. The percentages do not necessarily sum to $100 \%$ due to rounding. The numbers in parentheses indicate the total number of comments pertaining to each issue area. The entries in columns three and six report the p-values corresponding to two-tailed, umpaired difference of means tests. P-value entries appearing in bold indicate that the difference of means is statistically sigrificant at $p<.05$ (two-tailed tests). Issue areas representing less than $0.4 \%$ of the column totals in Table 1 are combined into the "Other Issues" category. The data contain information on Supreme Court nominees, both confirmed and unconfirmed, who appeared in front of an open session of the Senate Judiciary Committee since 1939. Nominees Marshall, Sotomayor, and Thomas represent the minority nominees, while nominees Ginsburg, O'Connor, and Sotomayor represent the female nominees

Second, senators pressed minority and female nominees much more heavily with regard to their judicial philosophies. Indeed, $14.2 \%$ of the questions from senators to minority nominees involved their preferred means of judicial interpretation, compared to $10.6 \%$ of questions for white nominees, while $13.9 \%$ of interrogatories addressed to female nominees involved judicial philosophy, compared to $10.8 \%$ for male nominees. As such, it is evident that senators are particularly interested in grilling female and minority nominees regarding their approaches to constitutional 
interpretation.

Third, female and minority nominees received fewer questions involving government operations and more questions implicating banking and finance. Senators pressed minority nominees on issues related to governmental operations, such as the separation of powers system, in only $1.5 \%$ of comments, while they queried white nominees about this topic $3.3 \%$ of the time. Female nominees received slightly more questions on government operations than minority nominees $(2.3 \%)$, but not as many questions as male nominees $(3.4 \%)$. In addition, white nominees and male nominees were asked about banking and finance more than twice as often as minority and female nominees.

While minority and female nominees share the differences discussed above, Table 7 reveals several points of departure. For example, minority nominees were interrogated with respect to criminal justice issues substantially more often than white nominees. Some $15.2 \%$ of questions from senators involved criminal justice for minority nominees, compared to only $6.2 \%$ for white nominees. Conversely, senators interrogated male nominees on this issue more often than female nominees: $8.1 \%$ for male nominees compared to $5.5 \%$ for female nominees. In addition, while minority nominees received fewer questions involving court administration and access to courts than did white nominees, female nominees were at the receiving end of more court administration and standing questions than male nominees. Finally, note that minority nominees received about twice as many queries implicating federalism and statutory interpretation than did white nominees, although there is no discernable difference between male and female nominees with regard to these issue areas.

\section{CONClusions: "THE MORE THINGS CHANGE, THE MORE THEY STAY THE SAME"}

Senate Judiciary Committee hearings of Supreme Court nominees represent the only institutionalized opportunity for nominees to engage in a face-to-face dialogue with members of the legislative branch. As part of the Senate's advise and consent role, these hearings provide information to senators and the American public regarding a host of issues implicating nominees' backgrounds, preferred means of judicial interpretation, and views on the most pressing issues of the day. Moreover, Senate Judiciary Committee

68. MOE., The Ghost of Ralph's Mom, on DITHER (Fatboy Records 2000). 
hearings represent a vital step as an individual makes the transformation from nominee to justice.

Despite the paramount significance of Senate Judiciary Committee hearings, there has been surprisingly little rigorous empirical scholarship on the topic. The purpose of this project is to fill this gap by contributing to our knowledge of confirmation politics and constitutional development by addressing the issues discussed by nominees and senators at the hearings. To do this, we created a novel dataset - the largest and most thorough of its kind-that tracks the issues discussed by all senators and nominees who testified at an open hearing of the Senate Judiciary Committee from 1939 to 2009.

In a very real way, the evidence we bring to bear makes it clear that the past seventy years of Senate Judiciary Committee hearings have been marked by both continuity and change. With regard to the number of comments made by nominees and senators, it is evident there was a steady increase in the amount of dialogue that transpires at the hearings, though it was Rehnquist's hearing for the Chief Justice position in 1986 that marked the most dramatic transformation, not Robert Bork's appearance before the committee in 1987. Following Rehnquist's hearing, the number of comments made by senators and nominees effectively plateaued to the very high levels that continue today.

As to the issues discussed at the hearings, our findings indicate that comments regarding hearing administration and chatter superabound and, with a few notable exceptions, this has always been the case. Indeed, from 1939 to 2009, more than $35 \%$ of comments involved hearing administration and chatter. Commentary pertaining to civil rights has exhibited more radical temporal change. While there was considerable variation with respect to civil rights dialogue until 1970, beginning with Powell's hearing in 1971, civil rights has been the dominant substantive issue area of discussion. Within the realm of civil rights, several issue areas also have undergone notable alteration. For example, issues of gender and sexual orientation discrimination did not appear until Carswell's hearing in 1970, but these issues have subsequently represented $15 \%$ of civil rights discussions. Similarly, although Roe v. Wade was decided in 1973, discussions of abortion did not manifest themselves at the hearings until O'Connor's hearing in 1981. Even since then, however, dialogue touching on abortion rights has constituted only $14.5 \%$ of civil rights commentary and $4.7 \%$ of hearing comments overall.

We have also uncovered some important differences with respect to the types of questions asked by Democratic and Republican senators. 
Republican senators seem to have developed a type of issue ownership with regard to questions pertaining to judicial philosophy, statutory interpretation, and national defense, pressing nominees on these issues substantially more than their Democratic counterparts. Conversely, Democrats interrogated nominees on criminal justice and labor relations issues almost twice as often as Republicans. What is more, Democratic senators grilled Republican nominees on civil rights more often than Republican senators, while Republican senators queried Democratic nominees on this issue more often than did Democratic senators. As such, it is apparent that senators from both political parties more often pressed nominees of the opposing party on civil rights issues, no doubt in an attempt to discern the extent to which the nominees' positions on salient civil rights subjects differ from their own.

In addition to illuminating the partisan differences in terms of the issues addressed at confirmation hearings, our results also provide evidence that female and minority nominees are differently treated than more traditional white male nominees. For example, senators pressed female and minority nominees substantially more often on issues of judicial philosophy and banking and finance. Moreover, senators engaged in far less comments involving hearing administration and chatter for female and minority nominees, indicating that senators interrogated female and minority nominees on more substantive issues than white male nominees.

These findings provide a solid empirical foundation for additional research in several emerging areas of political science and constitutional scholarship. For scholars interested in exploring causal mechanisms explaining the connection between public opinion and the evolution of constitutional law, the data presented here provide useful information regarding how senators and nominees use the confirmation process to validate, refute, or debate constitutional change over time. For those interested in studying the balance between judicial independence and judicial accountability, our data provide a useful starting point from which to judge the effectiveness of the confirmation hearings as a check on judicial power. Finally, scholars interested in reforming or changing the confirmation process will find much to interest them in our data involving how the process has, and has not, changed over time.

Our findings also should change the way confirmation hearings are discussed more generally. For example, an awareness that substantive issues such as civil rights, rather than abstracted theories of constitutional interpretation, have long dominated the hearings may 
change the dialogue about whether there is something wrong or inappropriate about the hearings as they are conducted today. The evidence regarding female and minority nominees should give pause to those concerned with the unique challenges the process presented to non-traditional nominees. Regardless of how participants in the ongoing dialogue about Supreme Court confirmations interpret and use these findings, however, our hope is that this project will create a foundation for more vigorous empirical work in this area in the future. 


\section{APPENDIX A}

\section{THE NOMINEES APPEARING IN THE SUPREME COURT CONFIRMATION HEARINGS DATABASE}

Appendix Table 1. The Nominees who Testified at the Senate Judiciary Committee Confirmation Hearings of Supreme Court Nominees, 1939-2009

\begin{tabular}{|c|c|c|c|}
\hline Nominee & $\begin{array}{l}\text { Appointing President } \\
\text { (President's Party) }\end{array}$ & $\begin{array}{l}\text { Year of } \\
\text { Hearing }\end{array}$ & Outcome \\
\hline Frankfurter & Roosevelt (D) & 1939 & Confirmed \\
\hline Jackson & Roosevelt (D) & 1941 & Confirmed \\
\hline Harlan & Eisenhower (R) & 1955 & Confirmed \\
\hline Brennan & Eisenhower (R) & 1957 & Confirmed \\
\hline Whittaker & Eisenhower (R) & 1957 & Confirmed \\
\hline Stewart & Eisenhower (R) & 1959 & Confirmed \\
\hline White & Kennedy (D) & 1962 & Confirmed \\
\hline Goldberg & Kennedy (D) & 1962 & Confirmed \\
\hline Fortas & Johnson (D) & 1965 & Confirmed \\
\hline Marshall & Johnson (D) & 1967 & Confirmed \\
\hline Fortas (Chief Justice) & Johnson (D) & 1968 & Withdrawn \\
\hline Thomberry & Johnson (D) & 1968 & Withdrawn \\
\hline Burger (Chicf Justice) & Nixon (R) & 1969 & Confirmed \\
\hline Haynsworth & Nixon (R) & 1969 & Rejected \\
\hline Carswell & Nixon (R) & 1970 & Rejected \\
\hline Blackmun & Nixon (R) & 1970 & Confirmed \\
\hline Powell & Nixon (R) & 1971 & Confirmed \\
\hline Rehnquist & Nixon (R) & 1971 & Confirmed \\
\hline Stevens & Ford $(\mathrm{R})$ & 1975 & Confirmed \\
\hline O'Connor & Reagan (R) & 1981 & Confirmed \\
\hline Rehnquist (Chief Justice) & Reagan (R) & 1986 & Confirmed \\
\hline Scalia & Reagan $(\mathrm{R})$ & 1986 & Confirmed \\
\hline Bork & Reagan (R) & 1987 & Rejected \\
\hline Kennedy & Reagan (R) & 1987 & Confirmed \\
\hline Souter & $\operatorname{Bush}($ G. H.W. $)(R)$ & 1990 & Confirmed \\
\hline Thomas & Bush (G. H.W.) (R) & 1991 & Confirmed \\
\hline Ginsburg & Clinton (D) & 1993 & Confirmed \\
\hline Breyer & Clinton (D) & 1994 & Confirmed \\
\hline Roberts (Chief Justice) & Bush (G.W.) (R) & 2005 & Confirmed \\
\hline Alito & Bush (G. W.) (R) & 2006 & Confirmed \\
\hline Sotomayor & Obama (D) & 2009 & Confirmed \\
\hline
\end{tabular}

(D) denotes Democratic president; (R) denotes Republican president. 


\section{APPENDIX B}

\section{THE ISSUES AND SUBISSUES APPEARING IN THE SUPREME COURT CONFIRMATION HEARINGS DATABASE}

Appendix Table 2. Issues, Subissues, and Itemized Subissues Appearing in the Data

\begin{tabular}{ll}
\hline Issue & Subissues and Itemized Subissues \\
\hline Macroeconomics & $\begin{array}{l}\text { Taxation, Tax Policy, and Tax Reform; Price Control and } \\
\text { Stabilization; Other and General Macroeconomic Issues }\end{array}$ \\
& Ethnic Minority and Racial Group Discrimination; Gender \\
Civil Rights & Handicap or Disease Discrimination; Voting Rights and Issues; \\
& Freedom of Speech and Religion; Right to Privacy and Access to \\
& Government Information; Abortion; Ant-Government \\
& Activities; Second Amendment; Speech: Political Speech and \\
& Campaign Finance; Speech: Commerial; Speech: Obscenity and \\
& Pornography; Speech: Other; Religion: Free Exercise; Religion: \\
& Establishment; Other Civil Rights Issues
\end{tabular}

Health

Labor and Employment

Education

Environment

Energy
Comprehensive Heal th Care Reform; Regutation of Drug Industry; Medical Devices, and Clinical Labs; Provider and Insuret Payment and Regulation; Prevention, Commuricable Diseases and Health Promotion; Longterm Care, Home Health, Terminally IIl, and Rehabilitation Services; Research and Development; Other Health Issues

Worker Sa fery and Protection, Occupational and Safety Health Administration (OSHA); Employment Benefits; Employee Relations and Labor Unions; Fair Labor Standards; Parental Leave and Child Care; Immigmtion and Refugee Issues; Other Iabor and Employment Issues

Higher Education; Elementary and Secondary Education; Education of Underprivileged Students; Special Education; Other Education Issues

Drinking Water Safety, Hazardous Waste and Toxic Chemical Regulation, Treatment, and Disposal; Species and Forest Protection; Other Environment Issues

Nuclear Energy and Nuclear Regulatory Commission Issues; Natural Gas and Oil; Coal 
Appendix Table 2. (continued)

Issue Subissues and Itemized Subissues

Criminal Justice

Social Welfare

Community Development and Housing

Banking, Finance and Domestic Commerce

Defense

Space, Technology and Communications

International Affairs and Aid
Executive Branch Agencies Dealing $W_{1}$ th Law and Crime; White Collar Crime and Organized Crime; Illegal Drug Production, Trafficking, and Control; Prisons; Juvenile Crime and the Juverile Justice System; Child Abuse and Child Pornogmaphy; Family Issues; Police, Fire, and Weapons Control; Riots and Crime Prevention; Death Penalty/Capital Punishment; Miranda Rights; Double Jeopardy; Search and Seizure; Right to Counsel; SelfIncrimination, Involuntary Confession, Refusal to Testify, Confrontation Chuse, Right to Confront Witnesses Against You; Habeas Corpus Reform; Other Criminal Justice Issues

Poverty and Assistance for Low-Income Families; Assistance to the Disabled and Handicapped; Other Social Welfare Issues

Low and Middle Income Housing Programs and Needs

U.S. Banking System and Financial Institution Regulation; Securities and Commodities Regulation; Corporate Mergets, Antitrust Regulation, and Corporate

Management Issues; Small Business Issues and Small Business Administration; Copyrights and Patents; Consumer Safery and Consumer Fraud; Sports and Gambling Regulation; Other Banking, Finance, and Domestic Commerce Issues

Military Intelligence, CIA, Espionage; Manpower, Military Personnel and Dependents (Army, Navy, Air Force, Marines), Military Courts; Civil Defense and Homeland Security; Direct War Related Issues; Relief of Claims Against U.S. Military

Broadcast Industry Regulation (TV, Cable, Radio); Computer Industry, Computer Securty, and General Issues Related to the Internet

Human Rights; Intemational Organizations Other Than Finance: United Nations (UN), UNESCO, Intemational Red Cross; Termorism, Hijacking; Other International Affairs and Aid Issues 
Appendix Table 2. (continued)

Issue

Govemment Operations

Public Land and Public Water

State and Local Government

Federalism

Miscellaneous Substantive Topics

Judicial Philosophy/Interpretive Methods

Hearing Administration and Chatter
Subissues and Itemized Subissues

Intergovernmental Relations; Government Efficiency and Bureaucratic Oversight; Nominations and Appointments; Presidential Impeachment and Scandal; Federal Government Branch Relations and Administrative Issues, Congressional Operations; Regulation of Political Campaigns, Political Advernising, PAC Regulation, Voter Registration, Government Ethics; Relief of Claims Against the U.S. Government; Constitutional Roles of the President and Congress in Declaring and Waging War, Limits on Presidential War Powers; Other Government Operations Issues

Native American Affairs; Natural Resources, Public Lands, and Forest Management; Water Resource Development and Research; U.S. Dependencies and Territorial Issues

State and Local Government Administration

Scope of Federal Preemption of State Law; Scope of Congressional Power Under Section Five of the Thirteenth, Fourteenth, or Fifteenth Amendments; Commerce Clause; Tenth Amendment; Eleventh

Amendment, State Sovereign Immunity; Other Federalism Issues

Judicial Administration; Statutory Interpretation; Best/Favorite Justices; Best/Favorite Cases or Opinions; Worst Cases or Opinions; Standing/Access to Courts; Non-Standing Justiciability Issues, Political Questions Doctrine, Mootness and Ripeness, Advisory Opinions

Judicial Restraint, Activism, Humility, Deference, Hubris; Original Intent, Original Meaning, Founders, Framers'

Purposes; Living Constitutionalism, Constitution as Evolving or Incorporating Current Norms; Text as Interpretuve Tool; Precedent, Stare Decisis; Separation of Powers; Other Judicial Philosophy Issues

Hearing Administration and Chatter; Chamcter and Background, Ethics of Nominec; Discussion of Media Coverage or Spin About the Hearings of the Nominee; Discussions of Pre-Hearing Conversations or Coaching or Contact Between the Nominee and Execurive Officials or Others 


\section{APPENDIX C}

\section{RELLABILITY ANALYSIS}

To conduct a reliability analysis of the data, we extracted a random sample of 92 pages of transcript (out of 3672 pages). Since the average number of observations per page is 7.57, we sought to obtain a sample of $\sim 2.5 \%$ of the data. Indeed, our sample constituted 715 observations, making up $2.57 \%$ of the data. This sample size gives us precision of $\pm 3.6 \%$ with $95 \%$ confidence. An independent coder collected the data for the reliability sample.

The number of observations in the main data file for the 92 pages of transcript is 718 . The number of observations in the random sample for the 92 pages of transcript is 717 . Thus, five observations do not match in the random sample and the main data file. As such, the agreement rate with regard to the number of observations is 99.3\%. Because we are unable to compare observations that are present in one dataset and absent from the other, we excluded the five non-matching observations from the reliability analysis.

Because the SUBISSUE and ITEMIZED SUBISSUE variables are not ordered, it was necessary to order them to conduct the reliability analysis. For example, a discussion of protests at abortion clinics would fall under the general issue of civil rights, and the subissues of freedom of speech/religion and abortion. Coder 1 may have ordered these such that ITEMIZED SUBISSUE $1=$ abortion and ITEMIZED SUBISSUE 2 = freedom of speech/religion, while Coder 2 may have ordered these such that ITEMIZED SUBISSUE $1=$ freedom of speech/religion and ITEMIZED SUBISSUE 2 = abortion. In such an instance, both coders agreed that the observation contained discussions of abortion and freedom of speech/religion, although they ordered these issues differently. To ensure the reliability analysis reflected the fact that the coders were in perfect agreement with respect to the subissues discussed in this example, the SUBISSUE and ITEMIZED SUBISSUE variables were ordered to match for the purpose of the reliability analysis.

We report information pertaining to the reliability of each variable below. This table reports the agreement rate for both samples, the expected agreement (that which would be expected by chance), along with a kappa statistic for each variable. The average agreement rate for all of the variables is $91.23 \%$, indicating that the data are quite reliable. Considered individually, it is evident that the agreement rate between coders is very high, ranging from a low of $59.16 \%$ to a high of $100.0 \%$ for several variables. Note the lowest 
agreement rates pertain to the SUBISSUE and ITEMIZED SUBISSUE 1 variables. We would expect these variables to have the lowest rate of agreement in that, if the coders differed as to the ISSUE variable, they necessarily differ with respect to the SUBISSUE and ITEMIZED SUBISSUE 1 variables, as those variables represent the subissues and itemized subissues within the ISSUE variable.

Although there are no firm guidelines with regard to exactly how strong kappa should be to determine a variable's reliability, Landis and Koch suggest that kappa values between 0.00 and 0.20 are poor; values between 0.21 and 0.40 are fair; values between 0.41 and 0.60 are moderate; values between 0.61 and 0.80 are substantial; and values above 0.81 are almost perfect. ${ }^{69}$ Using this as a guide, it is evident that the data are quite reliable. The average kappa score over all variables is 0.893 , which is almost perfect. Considered individually, none of the variables performs worse than moderate and almost all of the variables achieve substantial to almost perfect reliability.

69. Landis \& Koch, supra note 28 , at 165. 
Appendix Table 3. Reliability Analysis

\begin{tabular}{|c|c|c|c|c|c|}
\hline Variable & $\begin{array}{l}\text { Agreement } \\
\text { Rate }(\%)\end{array}$ & $\begin{array}{c}\text { Expected } \\
\text { Agreement }\end{array}$ & Kappa & $\begin{array}{c}\text { Standard } \\
\text { Error }\end{array}$ & Probability \\
\hline NOMINEE ID & 100.0 & 6.98 & 1.000 & 0.010 & $<0.001$ \\
\hline YEAR & 100.0 & 10.72 & 1.000 & 0.012 & $<0.001$ \\
\hline CITE & 96.36 & 1.62 & 0.963 & 0.005 & $<0.001$ \\
\hline PRESIDEN'T'S PARTY & 100.0 & 57.50 & 1.000 & 0.037 & $<0.001$ \\
\hline SENATE CONTROL & 99.16 & 55.40 & 0.981 & 0.037 & $<0.001$ \\
\hline SENATOR ID & 99.30 & 5.75 & 0.993 & 0.009 & $<0.001$ \\
\hline SENATOR'S PARTY & 91.60 & 50.83 & 0.829 & 0.037 & $<0.001$ \\
\hline COMMITTEE CHAIR & 100.0 & 26.16 & 1.000 & 0.021 & $<0.001$ \\
\hline SPEAKER & 99.72 & 50.77 & 0.994 & 0.037 & $<0.001$ \\
\hline ISSUE & 76.92 & 21.54 & 0.706 & 0.018 & $<0.001$ \\
\hline SUBISSUE & 59.16 & 7.15 & 0.560 & 0.001 & $<0.001$ \\
\hline ITEMIZED SUBISSUE 1 & 63.79 & 12.93 & 0.584 & 0.042 & $<0.001$ \\
\hline ITEMIZED SUBISSUE 2 & 100.0 & 72.22 & 1.000 & 0.408 & 0.007 \\
\hline ITEMIZED SUBISSUE 3 & \multicolumn{5}{|c|}{ insufficient observations for calculation } \\
\hline ITEMIZED SUBISSUE 4 & \multicolumn{5}{|c|}{ insufficient observations for calculation } \\
\hline ITEMIZED SUBISSUE 5 & \multicolumn{5}{|c|}{ insufficient observations for calculation } \\
\hline
\end{tabular}

NOMINEE ID is a unique identification number given to each nominee. YEAR represents the year of the confirmation hearing. CITE indicates the page number of the transcript on which the observation is coded. PRESIDENTS PARTY represents the political party of the president who appointed the nominee. SENATE CONTROL indicates which political party controlled the Senate at the time of the confirmation hearing. SENATOR ID is a unique identification number given to the questioning senator. SENATOR'S PARTY represents the political party of the questioning senator. COMMITTEE CHAIR indicates the identification number of the Chair of the Senate Judiciary Committee during each nominee's hearing. SPEAKER indicates whether the statcment being coded was made by the nominee or senator. ISSUE represents the main issue being discussed. SUBISSUE denotes the subissue being discussed. The ITEMIZED SUBISSUE variables code the itemized subissues being discussed. 
